\title{
Clouds and aerosols in Puerto Rico - a new evaluation
}

\author{
J. D. Allan ${ }^{1}$, D. Baumgardner ${ }^{2}$, G. B. Raga ${ }^{2}$, O. L. Mayol-Bracero ${ }^{3}$, F. Morales-García ${ }^{3}$, F. García-García ${ }^{2}$, \\ G. Montero-Martínez ${ }^{2}$, S. Borrmann ${ }^{4,5}$, J. Schneider ${ }^{5}$, S. Mertes $^{6}$, S. Walter ${ }^{5}$, M. Gysel ${ }^{7, *}$, U. Dusek $^{8,{ }^{* *}}$, \\ G. P. Frank ${ }^{8, * * *}$, and M. Krämer ${ }^{9}$ \\ ${ }^{1}$ National Centre for Atmospheric Science, University of Manchester, Manchester, UK \\ ${ }^{2}$ Centro de Ciencias de la Atmósfera, Universidad Nacional Autónoma de México, Mexico City, Mexico \\ ${ }^{3}$ Institute for Tropical Ecosystem Studies, University of Puerto Rico, San Juan, Puerto Rico \\ ${ }^{4}$ Institute for Atmospheric Physics, Johannes Gutenberg University, Mainz, Germany \\ ${ }^{5}$ Particle Chemistry Department, Max Planck Institute for Chemistry, Mainz, Germany \\ ${ }^{6}$ Leibniz-Institute for Tropospheric Research, Leipzig, Germany \\ ${ }^{7}$ School of Earth, Atmospheric \& Environmental Science, University of Manchester, Manchester, UK \\ ${ }^{8}$ Biogeochemistry Department, Max Planck Institute for Chemistry, Mainz, Germany \\ ${ }^{9}$ Institute for Chemistry and Dynamics of the Geosphere 1: Stratosphere, Forschungszentrum Jülich, Jülich, Germany \\ *now at: Paul Scherrer Institut, Villigen, Switzerland \\ ** now at: University of Utrecht, Utrecht, The Netherlands \\ *** now at: Department of Physics, Lund University, Lund, Sweden
}

Received: 20 August 2007 - Published in Atmos. Chem. Phys. Discuss.: 24 August 2007

Revised: 19 November 2007 - Accepted: 31 January 2008 - Published: 5 March 2008

\begin{abstract}
The influence of aerosols, both natural and anthropogenic, remains a major area of uncertainty when predicting the properties and behaviour of clouds and their influence on climate. In an attempt to better understand warm cloud formation in a tropical marine environment, a period of intensive measurements took place in December 2004 in Puerto Rico, using some of the latest developments in online instrumentation such as aerosol mass spectrometers, cloud condensation nuclei counters and a hygroscopicity tandem differential mobility analyser. Simultaneous online measurements of aerosol size distributions, composition, hygroscopicity and optical properties were made near the lighthouse of Cape San Juan in the north-eastern corner of the island and at the top of East Peak mountain (1040 m a.s.1.), the two sites separated by $17 \mathrm{~km}$. Additional measurements of the cloud droplet residual and interstitial aerosol properties were made at the mountain site, accompanied by measurements of cloud droplet size distributions, liquid water content and the chemical composition of cloud and rain water samples.

Both aerosol composition and cloud properties were found to be sensitive to wind sector. Air from the east-northeast
\end{abstract}

Correspondence to: D. Baumgardner

(darrel@servidor.unam.mx)
(ENE) was mostly free of anthropogenic influences, the submicron fraction being mainly composed of non-sea salt sulphate, while that from the east-southeast (ESE) was found to be moderately influenced by populated islands upwind, adding smaller $(<100 \mathrm{~nm})$, externally mixed, carbonaceous particles to the aerosol that increased the number concentrations by over a factor of 3 . This change in composition was also accompanied with a reduction in the measured hygroscopicity and fractional cloud activation potential of the aerosol. At the mountain site, the average cloud droplet concentrations increased from 193 to $519 \mathrm{~cm}^{-3}$, median volume diameter decreased from 20 to $14 \mu \mathrm{m}$ and the liquid water content increased from 0.24 to $0.31 \mathrm{~g} \mathrm{~m}^{-3}$ when the winds shifted from the ENE to ESE. Larger numbers of interstitial particles were recorded, most notably at sizes greater than $100 \mathrm{~nm}$, which were absent during clean conditions. The average size of the residual particles and concentrations of cloudwater nitrate, sulphate and insoluble material increased during polluted conditions.

Previous studies in Puerto Rico had reported the presence of a significant non-anthropogenic organic fraction in the aerosols measured and concluded that this was a factor controlling the in situ cloud properties. However, this was not observed in our case. In contrast to the $1.00 \pm 0.14 \mu \mathrm{g} \mathrm{m}^{-3}$

Published by Copernicus Publications on behalf of the European Geosciences Union. 
of organic carbon measured in 1992 and 1995, the organic matter measured in the current study of $0.17 \pm 0.35 \mu \mathrm{g} \mathrm{m}^{-3}$ is many times lower, most of which can be attributed to anthropogenic sources. During clean conditions, the submicron aerosol was observed to be almost entirely inorganic, an observation supported by the hygroscopicity measurements. This suggests that organic aerosols from marine sources may not be completely ubiquitous (either spatially or temporally) in this environment and requires further investigation to quantify their true extent and implications, with more extensive, longer-term sampling in conjunction with wind field analyses.

\section{Background and objectives}

Aerosol properties have long been recognized as an important influence on the dynamics and properties of clouds (McFiggans et al., 2006; Twomey, 1977). Quantitatively linking aerosol properties to cloud albedo and lifetime is a priority in climate science, as this is needed to address a large area of uncertainty in radiative forcing (Forster et al., 2007). This is especially true for marine clouds in tropical environments, as these have a dramatic influence on the planetary radiation budget due to both the high solar radiation flux and the low albedo of the surface they obscure. Recent advances in our understanding of interactions between aerosols and warm clouds has been driven in part by modern instrumentation that allows aerosol composition analyses to be performed online and in a greater detail than before (McMurry, 2000; Canagaratna et al., 2007). The object of the Puerto Rico Aerosol Cloud Interaction Study (PRACS) presented here was to perform detailed in situ measurements of both aerosol and cloud properties in a tropical environment at two sites simultaneously and compare the two in a "quasi Lagrangian" framework, as has been used in studies at other locations (e.g. Bower et al., 1999).

Puerto Rico is a tropical, Caribbean island whose fair weather climate is dominated by north-easterly trade winds. The island has been the site of a number of studies to measure the properties of aerosols in clean, maritime flow, taking advantage of air that is devoid of major anthropogenic influences. The second feature of Puerto Rico that makes it an attractive site for atmospheric research is the high frequency with which clouds envelop the mountain peaks and provides a region where the interaction of aerosols with clouds can be studied over extended periods of time. The first studies of this type were made in 1992 at the El Yunque mountain site (Novakov and Penner, 1993; Novakov et al., 1994). Sulphate and organic carbon (OC) were analyzed on aerosol samples taken with an eight stage micro-orifice uniform deposit impactor (MOUDI) and compared with measurements of condensation nuclei $(\mathrm{CN})$ and cloud condensation nuclei $(\mathrm{CCN})$. An inversion algorithm was invoked in order to esti- mate the number concentration as a function of size so that the mass distributions could be used to derive CCN composition. From these studies it was estimated that $37 \%$ of CCN were composed of sulphate with the remainder composed of OC. A relationship between CCN and non-sea salt (nss) sulphate was derived for clear and cloudy conditions and a good agreement was found between pre-cloud $\mathrm{CCN}$ and droplet concentrations. While sulphate constituted a large fraction of CCN mass, the researchers concluded that this had been added to the particles through processing after activation and therefore did not affect the initial CCN number concentrations, which were more dependent on the sea spray fraction.

In a follow-up study, measurements were made in 1995 at the Cape San Juan lighthouse located on the northeast corner of the island (Novakov et al., 1997). Analysis of aerosol particles less than $0.6 \mu \mathrm{m}$ in diameter, captured on quartz filters, showed that a large fraction of the OC was water soluble. In another project concluded in 1998, a chemical analysis of the OC in aerosol particles in regions upwind and to the NE of Puerto Rico showed that black carbon concentrations were low-to-non detectable and that there were no polycyclic aromatic hydrocarbons (PAHs) in the OC (Mayol-Bracero et al., 2001), suggesting that the OC was likely of natural origin. Another study at the same lighthouse location of Novakov et al. (1997) was conducted in 1999 using a MOUDI (Kirchstetter et al., 2000), but with a denuder to remove the positive artefacts produced by condensation of organic gases on the filters. The primary result from this experiment was to show that the non-anthropogenic OC is highly volatile and, perhaps even more importantly, that results from filter measurements should be interpreted with caution when sampling organics, otherwise serious artefacts can arise.

Evaluation of filters taken further upwind (Maria et al., 2002) from aircraft near St. Croix revealed that $60-90 \%$ of organic matter in the free troposphere was water soluble, with hydrophobic organic compounds accounting for 20 $50 \%$ of the organic matter in the marine boundary layer. In an evaluation of how aerosols may affect cloud formation over Puerto Rico, Comarazamy et al. (2006) examined the effect of aerosols on precipitation rate using a sun photometer to estimate aerosol loading and a cloud model to predict precipitation at the Arecibo Observatory. They predicted that cloud droplet concentrations are significantly larger and the precipitation diminished when formed in polluted air.

Following on from these works, a period of intensive measurements was conducted in Puerto Rico in December 2004, with the goal of improving further our understanding of warm cloud formation in a tropical marine environment and the role of marine organic aerosols though the use of some of the latest developments in online instrumentation, such as aerosol mass spectrometers, cloud condensation nuclei counters and a hygroscopicity tandem differential mobility analyser. While the previous studies provided valuable insights into potentially important processes, most of the composition measurements were made using bulk sampling methods that 


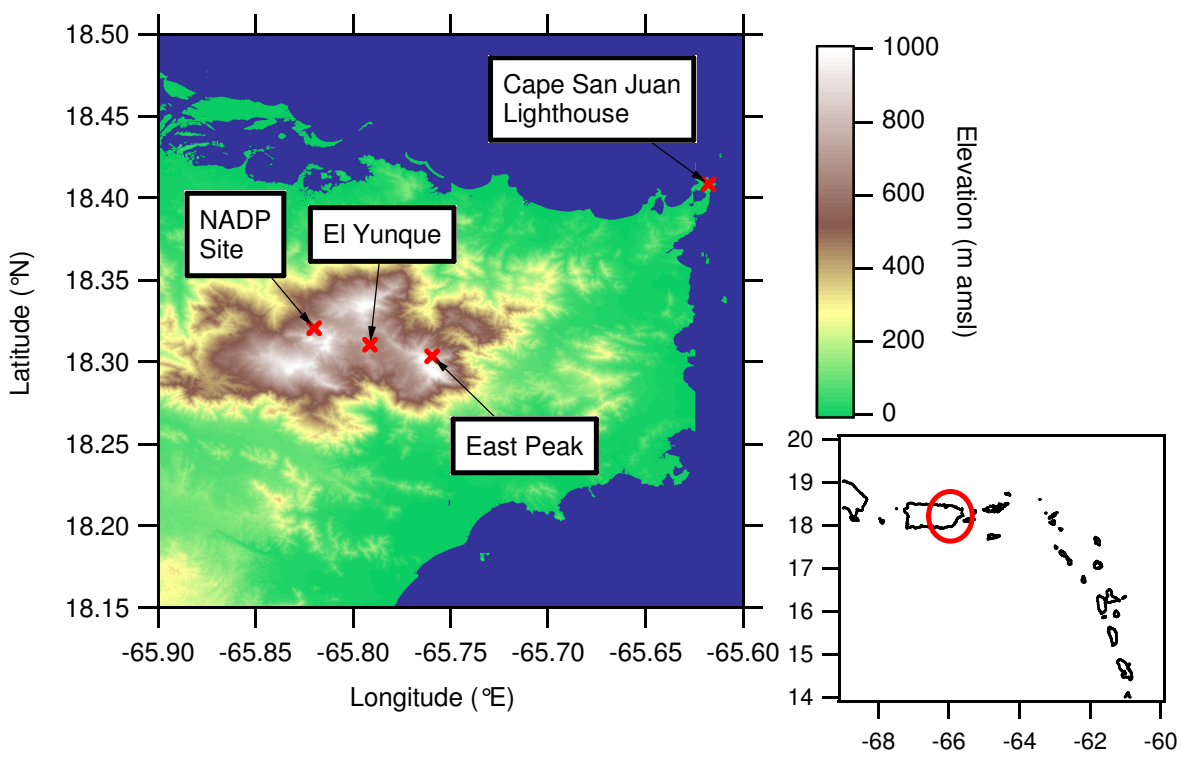

Fig. 1. Map of eastern Puerto Rico showing the Cape San Juan and East Peak sampling sites. Shown also is the site of the rain water sampler used by the National Acid Deposition Project (NADP) and the El Yunque site where previous aerosol measurements have been made.

require substantial exposure times to acquire a sample that is adequate for chemical analysis and that are susceptible to artefacts that contaminate the samples. Recent developments in the field of aerosol instrumentation have allowed the quantification of the composition and the hygroscopic properties of atmospheric aerosols online with high size and time resolution. These instruments have been in use for some time in northern mid-latitude environments (Zhang et al., 2007); however, their application to tropical locations has been very limited. Here we present measurements of aerosol properties measured using these instruments simultaneously at the Cape San Juan lighthouse and at East Peak, a mountain site in the El Yunque National Forest, and evaluate their relationships with meteorological conditions and cloud properties, also measured in situ. These sites are subsequently referred to as CSJ and EP, respectively, in this paper.

\section{Measurement and analysis methodology}

Figure 1 shows the locations of the measurement sites, CSJ $\left(18^{\circ} 22.85^{\prime} \mathrm{N}, 65^{\circ} 37.07^{\prime} \mathrm{W}\right)$ located at the northeast tip of the island and $\mathrm{EP}\left(18^{\circ} 18.21^{\prime} \mathrm{N}, 65^{\circ} 45.57^{\prime} \mathrm{W}\right)$, one of the highest points on the island ( $1040 \mathrm{~m}$ a.m.s.l.) and the farthest to the NE. The line of sight distance to the lighthouse installation was $17 \mathrm{~km}$. This location is close to El Yunque peak where previous measurements have been made of aerosol composition and cloud properties (Novakov and Penner, 1993; Novakov et al., 1994) and is also close to the precipitation sampler $\left(18^{\circ} 19.35^{\prime} \mathrm{N}, 65^{\circ} 49.22^{\prime} \mathrm{W}, 380 \mathrm{~m}\right.$ a.m.s.l. $)$ that is operated as part of the National Atmospheric Deposition Program
(NADP). The EP site experienced a layer of boundary-layer convective cloud on most days during these measurements.

The aerosol properties measured at each site were 1) concentrations of $\mathrm{CN}$ and $\mathrm{CCN}, 2$ ) particle number size distributions, 3) light absorption coefficients, 4) particle mass concentrations of sulphate, nitrate, ammonium and organic matter and 5) sub-saturated hygroscopic growth factors (lighthouse site only). The list of instrumentation is summarized in Table 1. All commercial instrumentation was operated under the manufacturer's normal operating procedures unless stated otherwise. The instruments that were operated at Cape San Juan were connected to a standard NOAA ESRL GMD ${ }^{1}$ aerosol inlet system that consists of a $10 \mathrm{~m}$ stack, a heater that maintained the relative humidity below $40 \%$ and a flow splitter (Sheridan et al., 2001).

Both of the Aerodyne aerosol mass spectrometer (AMS) systems were of the type originally introduced by Jayne et al. (2000) and used the data analysis methods described by Allan et al. (2004b, 2003). This system uses aerodynamic sizing, thermal vaporization, $70 \mathrm{eV}$ electron ionization and quadrupole mass spectrometry to deliver the size-resolved mass concentrations for the non-refractory, submicron component of the aerosol. This means that it is capable of measuring sulphate, particulate organic matter (POM), ammonium and nitrate, but is incapable of detecting elemental carbon, sea salt or mineral dust. In the absence of a reliable

\footnotetext{
${ }^{1}$ Global Monitoring Division, National Oceanic and Atmospheric Administration Earth System Research Laboratory, Boulder, CO, USA; http://www.cmdl.noaa.gov/aero/instrumentation/ inlet_system.html; http://www.esrl.noaa.gov/gmd/aero/net/index. html
} 
Table 1. List of instrumentation used during the project. The two sites are listed in the second column and referred to as: CSJ $=$ Cape San Juan lighthouse and EP $=$ East Peak. Diameter metric conventions are $D_{p}=$ physical, $D_{v a}=$ vacuum aerodynamic, $D_{m}=$ electrostatic mobility (DeCarlo et al., 2004). The last column lists the research institute that owns the instrumentation: UPR = University of Puerto Rico; UNAM = Universidad Nacional Autónoma de México, MPI-BG = Biogeochemistry Dept., Max Planck Institute for Chemistry; UM = University of Manchester, MPI-PC: Particle Chemistry Dept., Max Planck Institute for Chemistry/University of Mainz; LITR = Leibniz-Institute for Tropospheric Research.

\begin{tabular}{|c|c|c|c|c|c|}
\hline Parameter & Site & Instrument & Range & Uncertainty & Institute \\
\hline \multirow[t]{2}{*}{ CN Concentration } & CSJ & TSI Model 3022 & $0.004<D_{p}<3 \mu \mathrm{m}$ & $\begin{array}{l} \pm 5 \% \\
\text { (Quant et al., 1992) }\end{array}$ & UPR \\
\hline & $\mathrm{EP}$ & TSI Model 3010 & $0.010<D_{p}<3 \mu \mathrm{m}$ & $\begin{array}{l} \pm 5 \% \\
\text { (Quant et al., 1992) }\end{array}$ & UNAM \\
\hline \multirow[t]{2}{*}{ CCN Concentration } & CSJ & $\begin{array}{l}\text { Mainz parallel plate diffu- } \\
\text { sion chamber }\end{array}$ & $\mathrm{SS}=0.25,0.4,0.6,0.9,1.2 \%$ & $\begin{array}{l} \pm 0.05(\% \text { SS }) \\
\text { (Frank et al., 2007) }\end{array}$ & MPI-BG \\
\hline & $\mathrm{EP}$ & $\begin{array}{l}\text { U. Wyoming parallel plate } \\
\text { diffusion chamber }\end{array}$ & $\mathrm{SS}=0.5,1.0 \%$ & $\begin{array}{l} \pm 15 \% \\
\text { (Nenes et al., 2001) }\end{array}$ & UNAM \\
\hline Size-resolved CCN activation & CSJ & $\begin{array}{llll}\text { TSI } & 3071 \quad \text { DMA, } & \text { DMT } \\
\text { CCN } & \text { counter, TSI } & \text { CPC } \\
3762 & & & \end{array}$ & $\mathrm{SS}=0.1,0.25,0.4,0.6,1.0 \%$ & $\begin{array}{l} \pm 7 \% \text { (SS) } \\
\pm 6 \% \text { (activated fraction) } \\
\text { (Rose et al., 2008) }\end{array}$ & MPI-BG \\
\hline \multirow[t]{2}{*}{$\begin{array}{l}\text { Absorption Coefficient/BC Con- } \\
\text { centration }\end{array}$} & CSJ & $\begin{array}{l}\text { McGee } 7 \text { wavelength } \\
\text { Aethalometer }\end{array}$ & $\lambda=350 \mathrm{~nm}$ & $\begin{array}{l} \pm 30 \% \\
\text { (Weingartner et al., 2003) }\end{array}$ & UPR \\
\hline & $\mathrm{EP}$ & Radiance Research PSAP & $\lambda=550 \mathrm{~nm}$ & $\begin{array}{l} \pm 10 \% \\
\text { (Bond et al., 1999) }\end{array}$ & UNAM \\
\hline \multirow[t]{2}{*}{ Composition } & CSJ & $\begin{array}{l}\text { Aerodyne Quadrupole } \\
\text { Aerosol Mass Spectrometer }\end{array}$ & $40<D_{v a}<700 \mathrm{~nm}$ & $\begin{array}{l}10 \text { min averages }{ }^{\mathrm{a}}: \\
\pm 0.1\left(\mu \mathrm{g} \mathrm{m}^{-3} \mathrm{NH}_{4}^{+}, \text {org }\right) \\
\pm 0.02\left(\mu \mathrm{g} \mathrm{m}^{-3} \mathrm{SO}_{4}^{2-}\right) \\
\pm 0.01\left(\mu \mathrm{g} \mathrm{m}^{-3} \mathrm{NO}_{3}^{-}\right) \\
\text {(Allan et al., 2003) }\end{array}$ & UM \\
\hline & $\mathrm{EP}$ & $\begin{array}{l}\text { Aerodyne Quadrupole } \\
\text { Aerosol Mass Spectrometer }\end{array}$ & $40<D_{v a}<700 \mathrm{~nm}$ & As above & MPI-PC \\
\hline Growth Factor & CSJ & $\begin{array}{l}\text { University of Manchester } \\
\text { HTDMA }\end{array}$ & $\begin{array}{l}D_{m, \text { dry }}=49, \quad 100, \quad 200, \\
300 \mathrm{~nm} ; \mathrm{RH}=87 \%\end{array}$ & $\begin{array}{l} \pm 0.1 \text { (growth factor) } \\
\pm 0.2 \text { (\%RH) } \\
\text { (Cubison et al., 2005) }\end{array}$ & UM \\
\hline \multirow[t]{2}{*}{ Size distributions } & CSJ & $\begin{array}{l}\text { Grimm Model 5500/5403 } \\
\text { SMPS }\end{array}$ & $0.01<D_{m}<0.87 \mu \mathrm{m}$ & $\begin{array}{l} \pm 3 \% \text { (size) } \\
\pm 15 \% \text { (number) }\end{array}$ & MPI-BG \\
\hline & $\mathrm{EP}$ & $\begin{array}{l}\text { Grimm Model 5500/5403 } \\
\text { SMPS }\end{array}$ & $0.01<D_{m}<0.49 \mu \mathrm{m}$ & As above & MPI-PC \\
\hline $\mathrm{T}, \mathrm{RH}, \mathrm{P}$, winds, precipitation & $\mathrm{EP}$ & Davis weather station & N/A & & UNAM \\
\hline Cloud Droplet Concentrations & $\mathrm{EP}$ & $\begin{array}{l}\text { DMT Forward Scattering } \\
\text { Spectrometer Probe }\end{array}$ & $2<D_{p}<47 \mu \mathrm{m}$ & $\begin{array}{l} \pm 16 \% \text { (concentration) } \\
\pm 20 \% \text { (diameter) } \\
\text { (Baumgardner, 1983) }\end{array}$ & UNAM \\
\hline \multirow[t]{2}{*}{ Liquid Water Content } & EP & $\begin{array}{l}\text { Gerber Particle Volume } \\
\text { Monitor }\end{array}$ & $0.05<\mathrm{LWC}<3 \mathrm{~g} \mathrm{~m}^{-3}$ & $\begin{array}{l} \pm 20 \% \\
\text { (Wendisch, 1998) }\end{array}$ & LITR \\
\hline & $\mathrm{EP}$ & $\begin{array}{l}\text { Lyman-Alpha water vapor } \\
\text { detector }^{b}\end{array}$ & $0.05<\mathrm{LWC}<3 \mathrm{~g} \mathrm{~m}^{-3}$ & $\pm 20 \%$ & LITR \\
\hline Rainwater inorganic ions & $\mathrm{EP}$ & $\begin{array}{l}\text { AirChem Rainwater collec- } \\
\text { tor } \\
\text { Colorado State Cloud water } \\
\text { collector } \\
\text { Ion chromatography by the } \\
\text { Illinois State Water Survey } \\
\text { Analytical Laboratory }\end{array}$ & N/A & & $\begin{array}{l}\text { UNAM } \\
\text { UPR }\end{array}$ \\
\hline
\end{tabular}

${ }^{a}$ For longer averaging periods, the uncertainty is reduced in proportion to the square root of the averaging time

${ }^{\mathrm{b}}$ Used to evaluate CVI sampling characteristics 
external constraint, a collection efficiency of 0.5 was assumed based on validations performed in similar environments (Allan et al., 2004a). The equivalent black carbon (EBC) values are derived from an Aethalometer (Magee Scientific) and Particle Soot Absorption Photometer (PSAP, Radiance Research) using specific absorbencies of $19 \mathrm{~m}^{2} \mathrm{~g}^{-1}$ and $10 \mathrm{~m}^{2} \mathrm{~g}^{-1}$, respectively. These factors are by no means definitive (Bond and Bergstrom, 2006), but uncertainty in this factor will not effect the conclusions of our study given that the EBC is reported here only as a qualitative indicator for the presence of anthropogenic particles.

The design of the hygroscopicity tandem differential mobility analyzer (HTDMA) is given by Cubison et al. (2005) and a multi-triangle inversion method was applied (Gysel et al., 2007). This is an instrument designed to study the amount of water vapour taken up by dried, monodisperse aerosols exposed to high relative humidity $(87 \%$ was used during this study), which is related to the mixing states and water activity of the particle constituents. Two of the CCN counters used to measure total concentrations used the parallel plate diffusion chamber technique. The counter deployed at the lighthouse is an in-house design developed at the Max Planck Institute (Frank et al., 2007) and the counter used at East Peak is the University of Wyoming model 101 (Delene and Deshler, 2000; Delene et al., 1998). These are designed to count the number of particles that activate at selected supersaturations, thereby helping to predict the fraction of particles that will activate and form cloud droplets under a given cloud scenario. Additionally, size resolved CCN spectra were measured at CSJ using a Droplet Measurement Technologies continuous flow CCN counter (Lance et al., 2006; Rose et al., 2008; Roberts and Nenes, 2005) coupled to a Differential Mobility Analyzer (TSI 3071), to derived sizeresolved CCN spectra as described in Frank et al. (2007). Both CCN counters operated at CSJ were calibrated with respect to supersaturation and counting efficiency using ammonium sulphate particles according to the method described in Frank et al. (2007). The two scanning mobility particle sizers (SMPS) were included to measure the aerosol size distributions.

At the mountain site, cloud and rain water samples were taken for chemical analysis of the ion mass content. The precipitation sampler is the same model used by the NADP network (AirChem Inc.) and the cloud water sampler a Caltech Active Strand Cloud Collector Version 2 (Demoz et al., 1996), provided by Colorado State University. The cloud and water samples were sent to the Illinois State Water Survey Analytical Laboratory for analysis of $\mathrm{pH}$ and inorganic ion mass. This institute performs the analysis for all the samples collected by the NADP. The number, volume concentration and size distribution of insoluble particles in the cloud and rain water samples were analyzed at Forschungszentrum Jülich, Germany, with a Beckmann Multisizer 3 Coulter Counter that measures from 0.4 to $1.2 \mu \mathrm{m}$. In addition, the ion mass is derived from $\mathrm{pH}$ and conductivity measurements as described by Krämer et al. (1996). The cloud droplet size distributions were measured with a Forward Scattering Spectrometer Probe (FSSP, Droplet Measurement Technologies, Boulder, USA) and the liquid water content (LWC) was measured with a Particle Volume Monitor (PVM, Gerber Associates). An automated meteorological station (Davis Instruments) measured temperature, relative humidity, pressure, winds and precipitation.

Part of the instrumentation at East Peak was installed in a trailer located directly at the edge of an overlook facing the lighthouse. Three types of inlets were used to sample the aerosols: 1) total, 2) interstitial and 3) a counter flow virtual impactor (CVI). Air from the "total" inlet was heated to $50^{\circ} \mathrm{C}$ to dry the aerosol particles and evaporate water droplets when in cloud; hence, the particles measured from this inlet include interstitial particles and cloud droplet nuclei, when sampling cloudy air. The interstitial inlet separated water droplets from the air stream with an impactor (upper cutsize of $4 \mu \mathrm{m}$ ), such that only non-activated particles would be measured when in cloud. The remaining inlet, a CVI with a lower cut-size diameter of $5 \mu \mathrm{m}$ (Mertes et al., 2005), removed the interstitial particles, evaporated the water droplets and allowed the residual nuclei to be delivered to the aerosol instrumentation. The AMS and the SMPS alternated between the CVI and interstitial inlet. Due to technical problems, the AMS at East Peak was only operated between 8 December and 11 December. To eliminate any possible influence from a nearby generator, any data coincident with the EBC being greater than 3 standard deviations from the mean were excluded from the analysis.

The PVM was mounted on the roof of the trailer and the FSSP was installed horizontally on the roof of a small building approximately $10 \mathrm{~m}$ from the PVM. No aspirator was used to maintain a constant velocity of droplets through the FSSP but the prevailing wind maintained a steady flow through the probe from 2 to $10 \mathrm{~m} \mathrm{~s}^{-1}$ and the probe was aligned as close to parallel with the wind direction as possible. Given that the variable velocity through the FSSP was not directly measured, the flow volume was estimated by adjusting the sample volume such that the liquid water content (LWC) derived from the measured size distribution matched the LWC measured directly with the PVM. This approach was taken since the PVM is considered more accurate than the FSSP for measuring LWC when the mass is dominated by droplets less $30 \mu \mathrm{m}$ (Wendisch, 1998) whereas the FSSP is an accurate droplet counting instrument. Assuming that the sizing by the FSSP is accurate to within $20 \%$, the uncertainty in LWC is approximately $35 \%$ (Baumgardner, 1983). This leads to an estimated uncertainty in the derived sample volume of approximately $38 \%$, assuming that the PVM has an accuracy of $15 \%$, as cited by the manufacturer. Hence, the number concentration, derived from the FSSP droplet count divided by the sample volume, has an uncertainty of $38 \%$, assuming negligible counting losses due to coincidence. The FSSP was only operated during daylight hours given staff 
limitations but all the other instrumentation, at both measurement sites, were operated $24 \mathrm{~h}$ a day during the project.

\section{Results}

\subsection{Overview}

The measurements took place over the period 9-18 December 2004. The winds were east southeast (ESE) during the first three days, changing to the east northeast (ENE) on 13 December then back ESE on 15 December where they remained throughout the rest of the measurement program. While at no point were the two sites explicitly linked in a true Lagrangian manner, it is reasonable to assume that given their proximity, the measured compositions will be similar enough to make statements regarding the variations in composition of the regional aerosol. This assumption is backed up by the similarity in the $\mathrm{CN}$ concentration time series between the two sites shown in Fig. 2. Using principally the $\mathrm{CN}$ concentration and EBC mass concentrations, in conjunction with meteorological data, the observations during the campaign were stratified into three periods defined as "polluted", "clean" and "polluted". These time intervals, henceforth referred to as periods 1, 2 and 3, are shown in the time series of Figs. 2 and 3, along with the concentrations of $\mathrm{CN}$ and $\mathrm{CCN}$, mean hygroscopic growth factors and mass concentrations of inorganic ions, POM and EBC, all measured at the lighthouse. Table 2 lists the averages and standard deviations for these parameters during the three periods, as well as the $\mathrm{EBC}, \mathrm{CN}, \mathrm{CCN}$ and AMS-derived mass concentrations measured at East Peak. The spikes seen in the EBC time series are indicative of local pollution and the corresponding times were excluded from the averages.

The average $\mathrm{CN}$ concentrations measured at the two sites changed by approximately the same amount between the periods although the concentration at the East Peak was always somewhat higher. Periods 1 and 3 have much higher $\mathrm{CN}$ and the mass concentrations of OC and EBC at the lighthouse are also elevated, which is manifested in the reduced growth factors of the aerosol, possibly as a result of the addition of lower solubility material. This behaviour is most pronounced for period 3. There are more $\mathrm{CCN}$ during the polluted episodes but there are less relative to the number of $\mathrm{CN}$, since $\mathrm{CN}$ increased by a factor of greater than 3 , whereas $\mathrm{CCN}$ increased by a factor of 2 .

\subsection{Cape San Juan}

The AMS-measured nitrate was also found to have increased during period 3, although it must be noted that this is probably mainly in the form of sodium nitrate in sea salt particles, as nitrate does not coexist with sulphate on acidic particles. This is further supported by the fact that the overwhelming majority of nitrate signal is contained within $\mathrm{m} / z 30$ as opposed to 46 , which can be indicative of sodium as opposed to

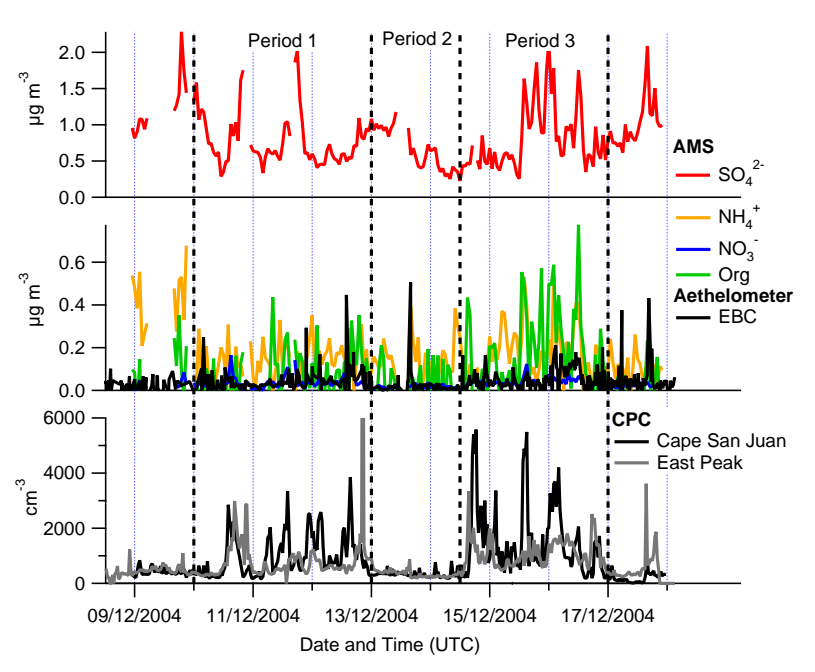

Fig. 2. Overview of the online aerosol measurements at the Cape San Juan site. The AMS data has been averaged down to a 1-h resolution for clarity. The CPC data from the East Peak site is also included to demonstrate the linkage between the two sites.

ammonium nitrate (Allan et al., 2004a; Topping et al., 2004). If this is the case, the values reported by the AMS will generally be low compared to the actual total concentrations, as sea salt particles are not detected efficiently due to their size and low volatility. POM concentrations are generally very low but these too show an increase during periods 1 and 3 . The ratio of POM to EBC during period 3, the period when the most significant amounts of carbonaceous aerosols were observed, was 2.66. This is greater than the primary OM/EC ratio of 1.4 reported by Zhang et al. (2005), which is to be expected, as there is likely to be a secondary organic component here. If an OM/OC ratio of 2.1 is assumed (Turpin and Lim, 2001), this corresponds to an OC/BC ratio of 1.27 , which is close to the $\mathrm{OC} / \mathrm{BC}$ ratios ranging from 1.3 to 2.4 reported by Novakov et al. (2005). However, as stated earlier, the absolute values of the EBC are to be treated with caution, especially at low black carbon concentrations where positive artefacts due to scattering and weakly absorbing material such as dust may be greatest. The fact that POM, EBC and $\mathrm{CN}$ exhibit such marked increases implies that they are linked, probably through the presence of sooty primary emissions in the form of small Aitken-mode particles. In the second period when the site was exposed to air from the clean northeasterly sector, there are reductions in POM and EBC to the point of being at or below the detection limits.

The growth factor spectra recorded by the HTDMA shown in Fig. 4 generally show a consistent mode around a growth factor of 1.5-1.6. This is quite close to the growth factors that are predicted for ammonium sulphate by the model of Topping et al. (2005a) (1.57, 1.60, 1.62 and 1.62 for dry diameters of 49,100, 200 and $300 \mathrm{~nm}$, respectively ${ }^{2}$ ), but

\footnotetext{
${ }^{2}$ D. O. Topping, University of Manchester, personal communication.
} 
Table 2. Averages of the AMS-derived composition, $\mathrm{CN}, \mathrm{CCN}$, humidity growth factor and cloud properties as a function of the different periods observed during the field campaign. CSJ = Cape San Juan lighthouse, EP=East Peak. Numbers in parentheses are standard deviations. Data for the EP AMS was unavailable for periods 2 and 3.

\begin{tabular}{|c|c|c|c|}
\hline Period: & 1 (ESE Winds) & 2 (NE Winds) & 3 (SE Winds) \\
\hline CSJ Sulphate $\left(\mathrm{ng} \mathrm{m}^{-3}\right)$ & $740(340)$ & $580(290)$ & $840(520)$ \\
\hline CSJ Nitrate $\left(\mathrm{ng} \mathrm{m}^{-3}\right)$ & $30(40)$ & $20(20)$ & $40(30)$ \\
\hline CSJ POM (ng m $\left.{ }^{-3}\right)$ & $40(340)$ & $10(320)$ & $170(350)$ \\
\hline CSJ Ammonium ( $\mathrm{ng} \mathrm{m}^{-3}$ ) & $140(240)$ & $140(270)$ & $180(210)$ \\
\hline EP Sulphate residual $\left(\mathrm{ng} \mathrm{m}^{-3}\right.$ ) & $920(500)$ & & \\
\hline EP Nitrate residual $\left(\mathrm{ng} \mathrm{m}^{-3}\right)$ & $130(120)$ & & \\
\hline EP Chloride residual ( $\mathrm{ng} \mathrm{m}^{-3}$ ) & $320(200)$ & & \\
\hline EP POM residual $\left(\mathrm{ng} \mathrm{m}^{-3}\right)$ & $<500$ & & \\
\hline EP Ammonium residual $\left(\mathrm{ng} \mathrm{m}^{-3}\right)$ & $<400$ & & \\
\hline EP Sulphate interstitial $\left(\mathrm{ng} \mathrm{m}^{-3}\right)$ & $40(80)$ & & \\
\hline EP Nitrate interstitial $\left(\mathrm{ng} \mathrm{m}^{-3}\right)$ & $<10$ & & \\
\hline EP Chloride interstitial $\left(\mathrm{ng} \mathrm{m}^{-3}\right)$ & $<20$ & & \\
\hline EP POM interstitial $\left(\mathrm{ng} \mathrm{m}^{-3}\right)$ & $<200$ & & \\
\hline EP Ammonium interstitial $\left(\mathrm{ng} \mathrm{m}^{-3}\right)$ & $<160$ & & \\
\hline $\operatorname{CSJ}$ EBC $\left(\mathrm{ng} \mathrm{m}^{-3}\right)$ & $39(37)$ & $15(18)$ & $64(48)$ \\
\hline $\operatorname{EP} \operatorname{EBC}\left(\mathrm{ng} \mathrm{m}^{-3}\right)$ & $35(53)$ & $38(65)$ & $59(47)$ \\
\hline $\operatorname{CSJ~CN~}\left(\mathrm{cm}^{-3}\right)$ & $719(485)$ & $287(135)$ & $904(498)$ \\
\hline $\operatorname{EPCN}\left(\mathrm{cm}^{-3}\right)$ & $1091(326)$ & $340(139)$ & $1159(341)$ \\
\hline CSJ $\mathrm{CCN}_{0.6}\left(\mathrm{~cm}^{-3}\right)$ & $311(178)$ & $171(122)$ & $373(164)$ \\
\hline $\mathrm{EP} \mathrm{CCN}_{0.5}\left(\mathrm{~cm}^{-3}\right)$ & $236(66)$ & $157(95)$ & $182(95)$ \\
\hline $\operatorname{CSJ} g(87 \%)_{49}$ & $1.49(0.05)$ & $1.56(0.08)$ & $1.46(0.04)$ \\
\hline CSJ $g(87 \%)_{100}$ & $1.52(0.04)$ & $1.54(0.02)$ & $1.48(0.05)$ \\
\hline CSJ $g(87 \%)_{200}$ & $1.63(0.04)$ & $1.64(0.05)$ & $1.52(0.08)$ \\
\hline $\operatorname{CSJ} g(87 \%)_{300}$ & $1.74(0.07)$ & $1.78(0.06)$ & $1.60(0.12)$ \\
\hline EP Droplet concentration $\left(\mathrm{cm}^{-3}\right)$ & $519(186)$ & $193(84)$ & $410(180)$ \\
\hline EP Median Volume Diameter $(\mu \mathrm{m})$ & $16(3)$ & $20(3)$ & $14(3)$ \\
\hline EP Liquid Water Content $\left(\mathrm{g} \mathrm{m}^{-3}\right)$ & $0.31(0.16)$ & $0.24(0.1)$ & $0.28(0.16)$ \\
\hline EP Rain Rate $\left(\mathrm{mm} \mathrm{h}^{-1}\right)$ & $0.32(0.06)$ & $0.39(0.18)$ & $0.40(0.19)$ \\
\hline
\end{tabular}

lower than what would be expected for ammonium bisulphate $(1.84,1.86,1.87$ and 1.88$)$. It may be that the particles are principally ammonium sulphate or they are a more acidified form of sulphate that is internally mixed with a less soluble component. The latter is deemed unlikely given the consistency of the growth factors, which would require a constant mass ratio between the two components to achieve this. Unfortunately, without adequate size-resolved ammonium measurements from the AMS (which are not possible in this experiment due to signal-to-noise limitations), it is difficult to definitively say which is happening. In addition to the main mode, there is frequently an additional component of high growth factor $(\approx 2)$ particles, in particular for the larger dry sizes. These are almost certainly sea spray particles, although their growth factors are often lower than those expected of pure sodium chloride. This could be due to processing (the predicted growth factor of sodium nitrate is around $18 \%$ lower), or an internally mixed component of reduced solubility. However, the fact that this activity is gen- erally less significant than the principle mode shows that the majority of particles of these dry sizes are not of this type, so will be less significant a fraction of the total number. During period 2, the modal growth factor for $300 \mathrm{~nm}$ particles increases to around 1.7, which could be indicative of more acidic sulphate particles. During period 3 (and to a lesser extent period 1), the main mode persists, but a significant "shoulder" of particles of a growth factor of less than 1.2 appears, which is likely to be externally mixed soot particles, consistent with the increased EBC and POM concentrations measured.

The hygroscopic behaviour is also reflected in the $\mathrm{CCN}$ measurements. Figure 5 shows size-resolved CCN activation efficiencies as a function of different supersaturations for parts of periods 1 and 2 (data for period 3 were unavailable). During period 1 , the small particles $(<100 \mathrm{~nm})$ are less easily activated compared to period 2 and the $\mathrm{CCN}$ spectra do not always reach unity at high supersaturations. This is in agreement with the lower HTDMA growth factors observed 


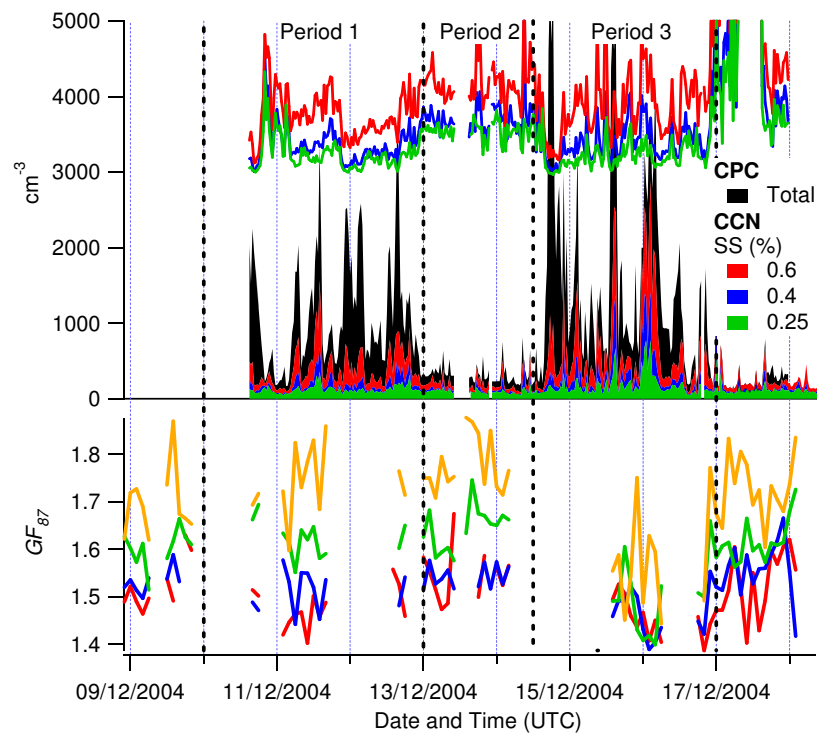

Fig. 3. $\mathrm{CCN}$ number concentrations and mean HTDMA growth factors measured at the Cape San Juan site. The CCN fractions are the ratios of $\mathrm{CCN}$ concentrations to $\mathrm{CPC}$ counts.

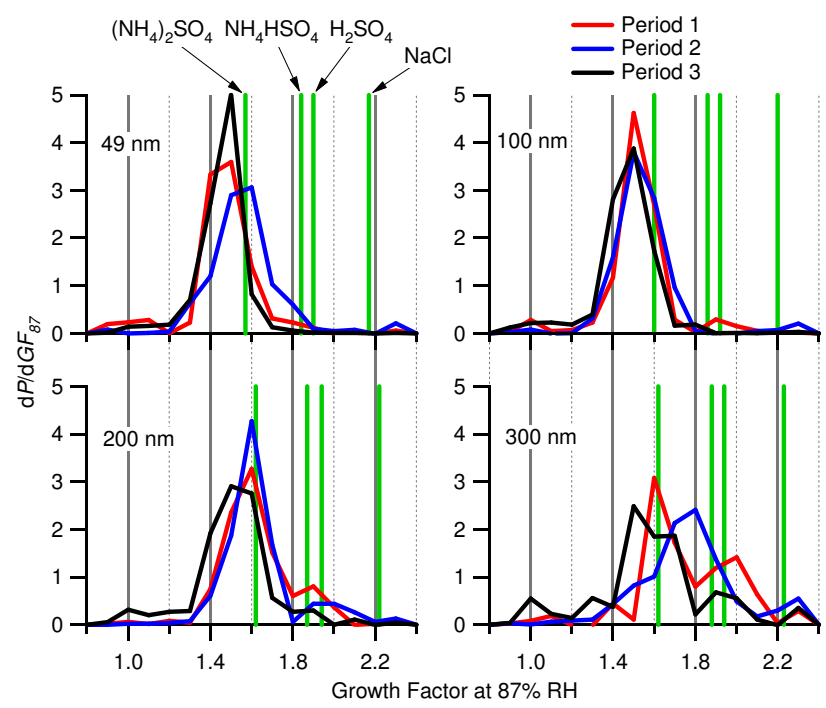

Fig. 4. Retrieved HTDMA growth factor spectra (as normalised frequency distributions) from the Cape San Juan site divided into the three periods identified in the text. Predicted growth factors for ammonium sulphate, ammonium bisulphate, sulphuric acid and sodium chloride are also show, based on the model of Topping et al. (2005a). Within the measurement uncertainties, the modes of the spectra are close to the predicted growth factors of ammonium sulphate. Note the absence of a low growth factor mode during period 2 .

during this period (Fig. 4) and is consistent with there being an increased number of POM-containing Aitken mode particles, assuming that these particles are less hygroscopic than the inorganic particles. The activation diameters for pure am-

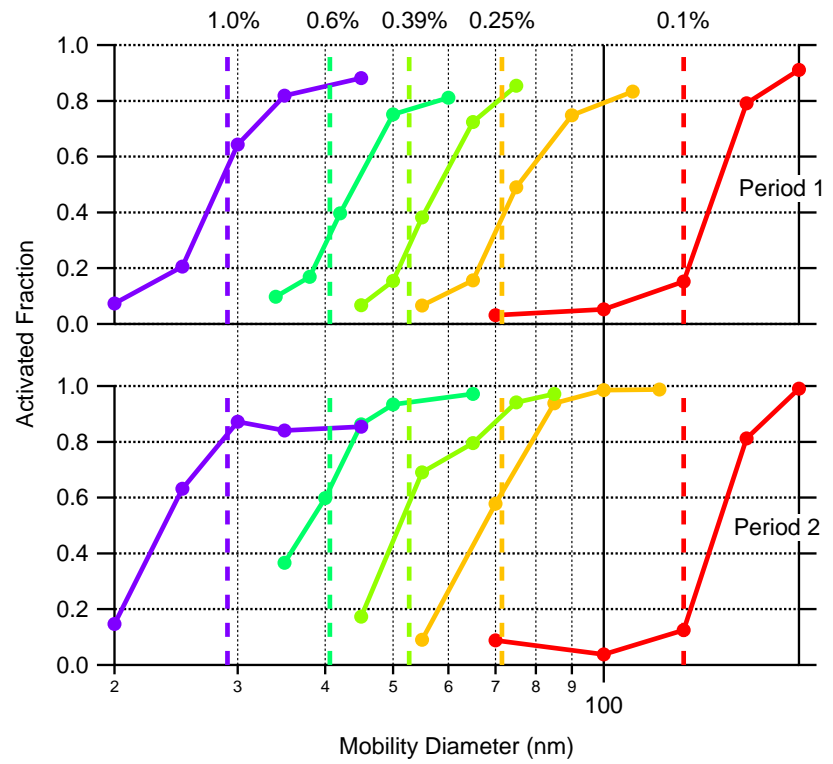

Fig. 5. Size-resolved $\mathrm{CCN}$ activation efficiencies for periods 1 and 2, taken from the DMA-DMT CCN instrument configuration. The dashed vertical lines are theoretical activation diameters for pure ammonium sulphate particles for the supersaturations used during measurement $(0.1,0.25,0.39,0.6$ and $1.0 \%)$. No data is available for period 3 .

monium sulphate were calculated using the Köhler equation with a variable Van't Hoff factor as is used in the calibration of the CCN counters (Frank et al., 2007) and are shown as dashed vertical lines on the figure. The activation behaviour is roughly consistent with these during in period 1 , also in agreement with the HTDMA growth factors. In period 2 the particles are, in some cases, somewhat more $\mathrm{CCN}$-active than pure ammonium sulphate, especially for the smaller particles. This could, much like the HTDMA growth factors, indicate the presence of acidified sulphate particles. Sea salt particles could also be responsible, but as these are mechanically generated, a bias in this discrepancy towards the larger dry sizes would be expected, which is not the case here.

The frequency distributions shown in Fig. 6 highlight the differences in some of the aerosol properties related to air mass origins. The frequency of occurrence for each of the three cases (red, blue and black) is given as a percentage of all events during the respective time periods. The same number of intervals is used for the three cases and for each aerosol parameter. Overall, the measurements during period 3 show the most signs of influence from anthropogenic emissions. The average values of the $\mathrm{CN}$ at the lighthouse and East Peak change by a factor of more than three during periods of SE winds, although there are large variations during both clean and polluted periods as seen in the standard deviations. The CCN concentration, measured at $0.6 \%$ supersaturation was on average less than $200 \mathrm{~cm}^{-3}$ during the clean period at the lighthouse but more than doubled between the second and 

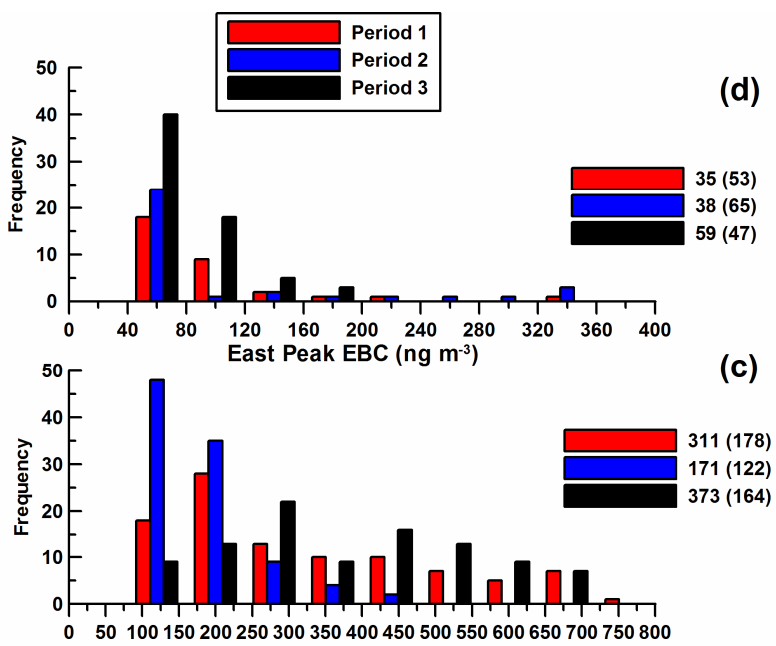

Lighthouse .6\% CCN Concentration $\left(\mathrm{cm}^{-3}\right)$
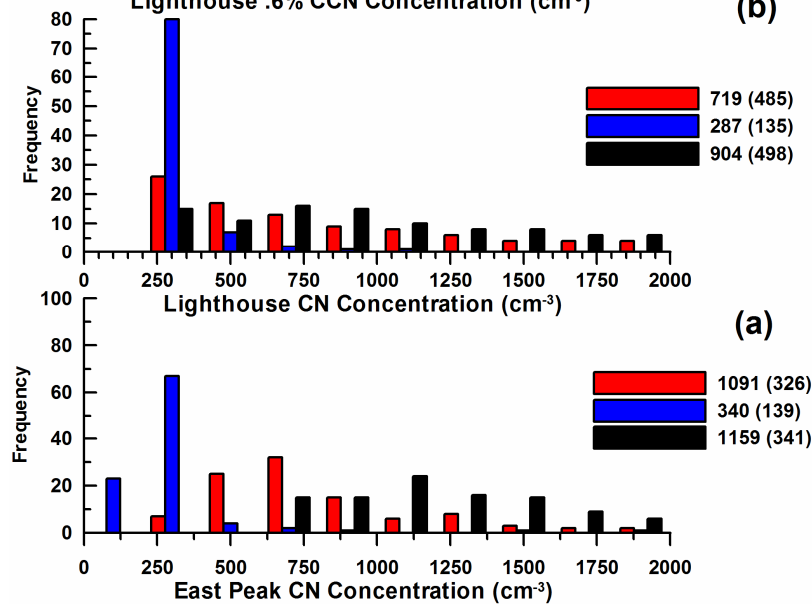

Fig. 6. Frequency distributions of $\mathrm{CN}, \mathrm{CCN}$ and $\mathrm{EBC}$ concentrations during the three periods at the different sites.

third periods. The EBC at East Peak is similar between periods 1 and 2 , then increases by nearly a factor of two between periods 2 and 3 .

The variations in particle composition are also evident when comparing the averaged size distributions measured with the scanning mobility particle sizer (SMPS). As shown in Fig. 7, the overall number concentrations of Aitken mode $\left(D_{m}<100 \mathrm{~nm}\right)$ particles are significantly elevated for periods 1 and 3, which will be manifested in the total $\mathrm{CN}$ and $\mathrm{CCN}$ number concentrations. In the accumulation mode $\left(D_{m} \approx 200 \mathrm{~nm}\right)$, the increases during periods 1 and 3 are more subtle, but are also evident in the AMS sulphate mass distributions from the lighthouse. All of the distributions also contain a "shoulder" in the lower particle diameters, which corresponds to the Aitken modes in the number distributions. A discernable organic mass distribution is only found during period 3, which is more biased towards the smaller particle sizes compared to sulphate, consistent with it being associated with smaller primary particles.
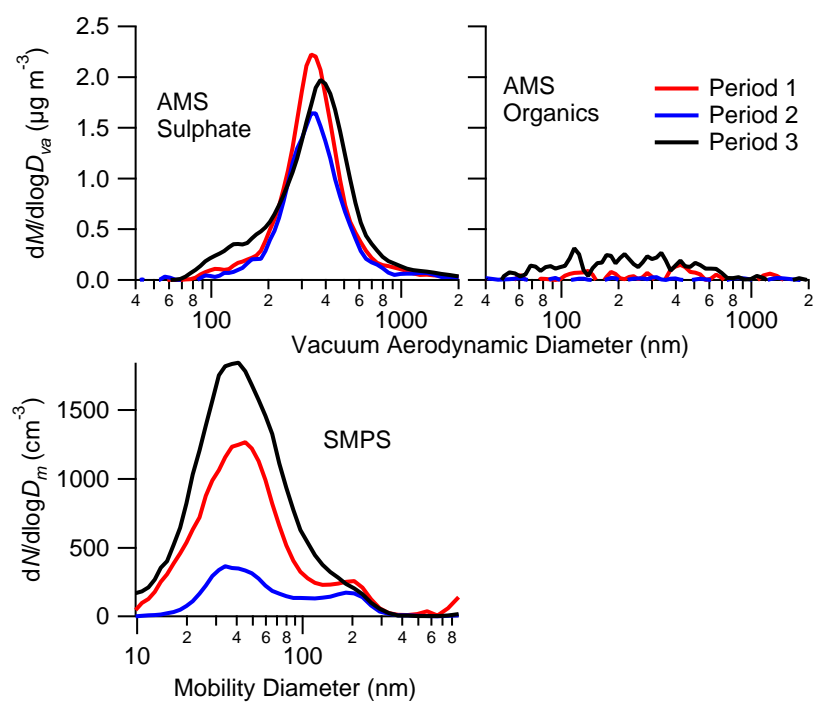

Fig. 7. Cape San Juan particle mass and number distributions for the three identified periods. Due to signal-to-noise limitations, only sulphate and organic distributions could be reliably derived from the AMS data.

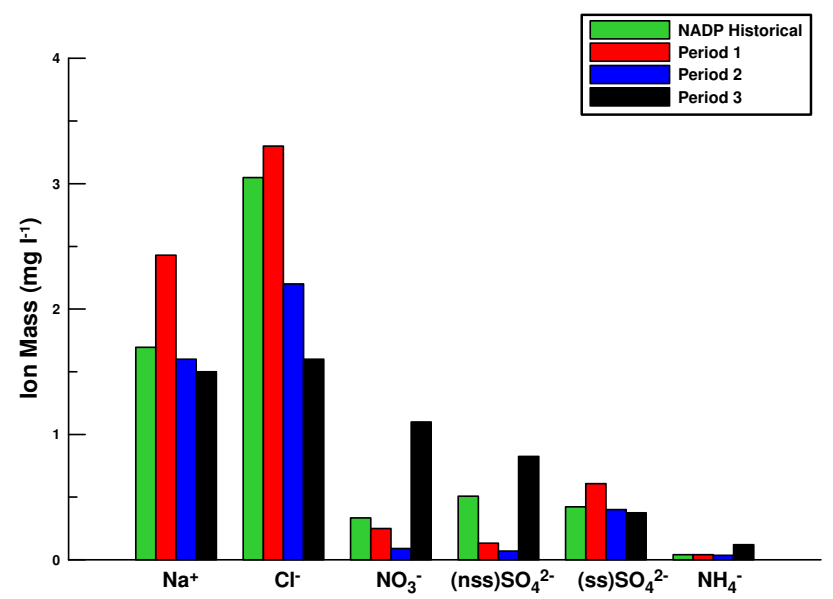

Fig. 8. Average inorganic solute composition of cloud and rainwater samples for the three periods, with the historical NADP data shown for comparison.

\subsection{East Peak}

The difference in air mass origin during the three periods was also manifested at the East Peak in the cloud/rain water chemistry. Figure 8 shows the mass concentrations of selected ions, stratified by time period. Also shown in this figure are averages from the NADP archives from 1985 to 2005. The major component during all periods was sea salt. The sea salt (ss) sulphate, calculated using a mass ratio of $\mathrm{SO}_{4}^{2-}$ to $\mathrm{Na}^{+}$of 0.252 (Quinn et al., 2000). The concentrations of non-sea salt (nss) sulphate and nitrate were significantly greater in the third period compared to the other 

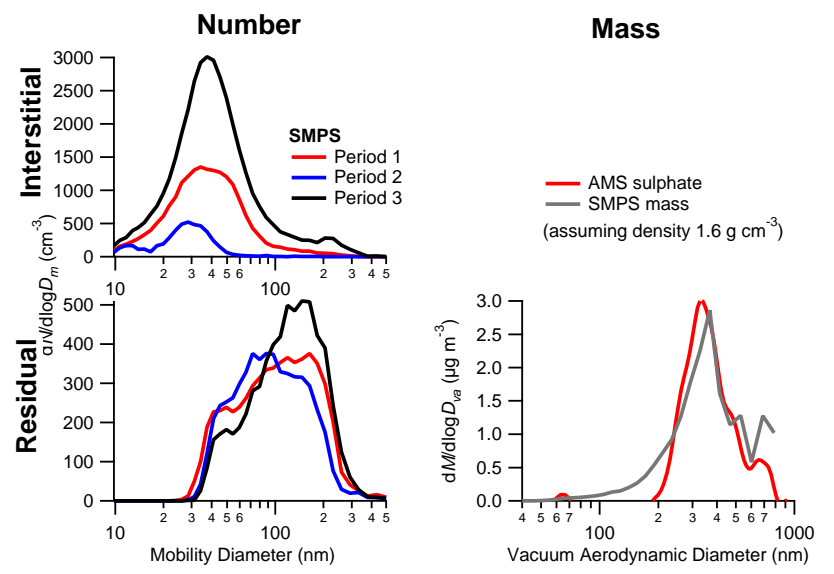

Fig. 9. Interstitial and cloud residual size distributions for the three periods as measured using the SMPS at East Peak. Also included is the averaged residual chemical mass distribution of residual particles measured with the AMS connected to the CVI on 10 December, although only sulphate is included, as this was the only species above detection limit for size-resolved data.

periods, probably due to the oxidation of anthropogenic $\mathrm{SO}_{2}$ and $\mathrm{NO}_{\mathrm{x}}$. It is also of interest to note that the chloride to sodium ratio was much smaller during period 3 , which indicates that some of the chloride will have been displaced by the uptake of nitric and/or sulphuric acid onto the sea salt particles. The same conclusions were reached during measurements performed in January 2005 at the same site as part of the Rain In Cumulus over the Ocean experiment (Gioda et al., $2008^{3}$ ).

Due to technical issues, the data coverage of composition measurements using the AMS downstream of the CVI at East Peak was not extensive, but the data that were collected during part of period 1 (only on 10 December) consistently showed particle residuals mainly composed of sulphate, with small amounts of nitrate and chloride (Table 2). The detection limit for organic matter of the AMS operated on East Peak was $0.2 \mu \mathrm{g} \mathrm{m}^{-3}$ for the averaged time period. The cloud residual data has to include corrections due to the CVI sampling efficiency and enrichment, which equate to factors of 10 and 0.25 , respectively, yielding an ambient detection limit of $0.5 \mu \mathrm{g} \mathrm{m}^{-3}$. The average concentration of organic matter was clearly below this detection limit. Figure 9 shows a size distribution of the droplet residual aerosol mass concentration of sulphate compared with a mass size distribution estimated from the SMPS. Chloride size distributions were not recorded. The size distribution is very similar to that measured by the AMS at CSJ (Fig. 7). Adding up the AMS

\footnotetext{
${ }^{3}$ Gioda, A., Mayol-Bracero, O. L., Morales-García, F., Collett, J., Decesari, S., Emblico, L., Facchini, M. C., Morales-De Jesús, R. J., Mertes, S., Borrmann, S., Walter, S., and Schneider, J.: Chemical composition of cloud water in the Puerto Rican tropical trade winds, Water Air Soil Poll., submitted, 2008.
}

mass concentrations leads to a slightly greater total than what can be inferred from the SMPS data, which is probably due to uncertainties in the particle density and AMS collection efficiency. Through the absence of any measurable organics, these results suggest that no significant amounts of submicron organic particles (primary or secondary) were emitted by the rain forest or human activity in the intervening distance between the site and the coast. In the interstitial aerosol measured at East Peak all substances detectable by the AMS were below detection limit with the exception of sulphate (Table 2). The measured sulphate mass concentrations in the cloud residuals were higher by a factor of about 20 . While it is possible that some of the mass could have been added in the cloud through aqueous processes, the fact that very little remained in the interstitial aerosol indicates that almost all sulphate-containing particles were activated as $\mathrm{CCN}$.

Sodium chloride would probably dominate the larger residual particles but this is undetectable by the AMS. In spite of this, significant amounts of chloride (detected as $\mathrm{HCl}^{+}$after ionisation) were measured by the AMS in the residuals at East Peak, but not in the interstitial aerosol. A speculative explanation for this finding may be that aqueous chloride is displaced by sulphate and nitrate absorbed within the cloud and converted to $\mathrm{HCl}$ as the cloud droplet dries in the CVI. Being volatile, this is expected to evaporate from the particle, but a fraction may not have time before the aerosol is passed to the instrument, so will be detected on the particles by the AMS.

An analysis of the total ion mass, insoluble mass, insoluble particle number concentrations and median diameter of the insoluble particles in the cloud and rain water samples is listed in Table 4 for periods 1 and 2. The total ion mass and insoluble mass in the cloud water is nearly ten times more than measured in the rain water. The total ion mass and insoluble mass decrease by more than a factor of two between the first and second periods. The insoluble mass may be sooty particles or possibly dust. There is little change in the median insoluble particle diameter between periods 1 and 2 for either the cloud or rain water samples.

In an effort to better understand the activation behaviour of the particles, the SMPS size distributions were compared between the times spent sampling via the CVI residual line and the interstitial inlet during cloudy periods (defined as those time intervals when the LWC was greater than $0.1 \mathrm{~g} \mathrm{~m}^{-3}$ and the cloud droplet number concentration greater than $100 \mathrm{~cm}^{-3}$ for at least twenty minutes). The averaged distributions are shown in Fig. 9. In addition to the larger numbers of interstitial particles overall, the more polluted cases show a significant number of larger particles that are not activated within the clouds. The interstitial particles observed during period 1 are very small $(30-60 \mathrm{~nm})$, which due to their small size are not expected to contribute significantly to the chemical mass concentrations. Period 3 shows significant numbers of non-activated particles of sizes up to $300 \mathrm{~nm}$, whereas in period 2, there are few particles above $50 \mathrm{~nm}$ that 
are not activated. These particles must be lower-solubility particles, externally mixed and with higher critical supersaturations than those that activate in the cloud. The HTDMA growth factor distributions at CSJ confirm the presence of a fraction of externally mixed non-hygroscopic particles at dry size $300 \mathrm{~nm}$ during period 3 , indicating the presence of a lower solubility component. In the residual particles, the number of particles smaller than $80 \mathrm{~nm}$ is fewest in period 3 and greatest during period 2, which may be another manifestation of the increase in the overall solubility of particles, although the addition of secondary material in polluted conditions through aqueous processes in the cloud may be partly responsible for an increase in the size of the residual particles (Chandler et al., 1989).

The frequency diagrams shown in Fig. 10 illustrate the changes in bulk cloud properties as a function of air mass origin. The frequency of events is presented in the same manner as discussed for Fig. 6 . The figure shows that the average droplet concentrations change by a factor of two between the clean and first polluted period, by $25 \%$ from the clean to the second polluted period and that these concentrations are consistent with the average $\mathrm{CCN}$ concentrations that were measured at the lighthouse and East Peak (Table 2). The average value of the median volume diameter is $4 \mu \mathrm{m}$ larger during the clean period $(20 \mu \mathrm{m})$ than during the polluted period 1 $(16 \mu \mathrm{m})$ and $6 \mu \mathrm{m}$ larger than period $3(14 \mu \mathrm{m})$. The LWC during the clean period is $0.24 \mathrm{gm}^{-3}$ compared to $0.30 \mathrm{gm}^{-3}$ in the periods influenced by anthropogenic emissions. The average precipitation during all periods is nearly the same.

The 00:00 UTC and 12:00 UTC (19:00 and 07:00 local time) soundings from the San Juan International airport ${ }^{4}$, launched by the US National Weather Service, were evaluated to compare the meteorological state of the atmosphere during the three periods. The droplet concentration and size distribution, in addition to being sensitive to the characteristics of the $\mathrm{CCN}$ at cloud base, will depend on the vertical profile of temperature and water vapor and the vertical velocity. The pressure of the lifted condensation level (LCL) is used as an indicator of expected cloud base and the precipitable water $(\mathrm{PW})$ as a measure of potential rain amounts. The average LCLs for the three periods were $956 \pm 8 \mathrm{mb}, 962 \pm 11 \mathrm{mb}$, and $963 \pm 4 \mathrm{mb}$, respectively, indicating little difference in expected cloud bases for the three identified periods. The average PW for these same periods was $40 \pm 6 \mathrm{~mm}, 44 \pm 11 \mathrm{~mm}$, and $50 \pm 5 \mathrm{~mm}$. There is a positive trend in PW during the nine days of the project; however, this is not reflected in either the precipitation rates or in situ liquid water contents that were measured (Table 2 and Fig. 10). The mountain site was approximately $300 \mathrm{~m}$ above cloud base as estimated from the pressure measured at the site and the photos that were recorded from the lighthouse every five minutes with a web camera. These photos showed that the daytime cloud

\footnotetext{
${ }^{4}$ Data provided by the University of Wyoming, http://weather. uwyo.edu/upperair/sounding.html
}
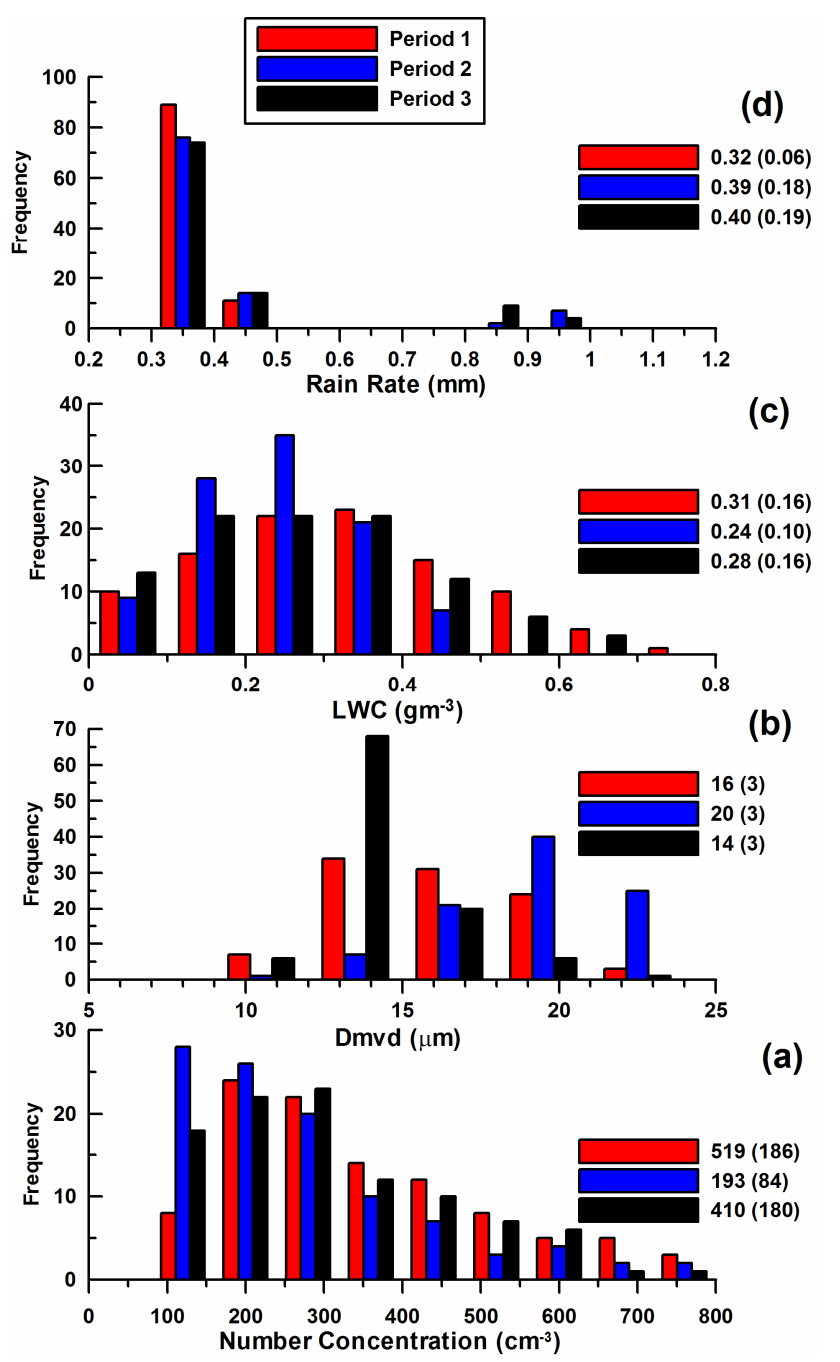

Fig. 10. Frequency distributions of in situ cloud microphysical data from the three periods, measured at the East Peak site.

bases and tops were not visibly different for the three periods, consistent with the sounding information that indicated fairly constant pressures and temperature at cloud base during the observational period.

The vertical velocity for the three time periods was not directly measured. In order to assess the effect of changes in vertical velocity at cloud base versus changes in the $\mathrm{CCN}$ concentrations, we ran a closed parcel model with constant updraft to estimate droplet activation, within $300 \mathrm{~m}$ of cloud base. The model incorporates the parameterization introduced by Twomey and Wojciechowski (1969), of the CCN concentration (C) as a function of supersaturation, $S$, of the form $C=C 0 S k$. The values of $C 0$ and $k$ were estimated from the $\mathrm{CCN}$ measurements made at the lighthouse site. Table 3 shows the results of the model for constant updraft velocities of 0.2 and $1 \mathrm{~ms}^{-1}$ and for the $C 0$ and $k$ values derived for the clean and polluted periods. It can be seen in the table 
Table 3. Results of a closed parcel model with constant updraft velocity $(W)$, based on the observed $\mathrm{CCN}$ characteristics at the lighthouse, for the three periods identified in the study. Note that periods 1 and 3 had similar characteristics, so are grouped for these purposes.

\begin{tabular}{ccccc}
\hline Period & $\mathrm{C} 0$ & $\mathrm{~K}$ & $N_{D}\left(W=0.2 \mathrm{~ms}^{-1}\right)$ & $N_{D}\left(W=0.2 \mathrm{~ms}^{-1}\right)$ \\
\hline $1 \& 3$ & 700 & 0.8 & 373 & 397 \\
2 & 250 & 0.8 & 142 & 172 \\
\hline
\end{tabular}

that the droplet concentration, $N_{D}$, predicted for an altitude of $300 \mathrm{~m}$ above cloud base increases by less than $20 \%$ when the vertical velocity is increased by a factor of five. The observed increase in the $\mathrm{CCN}$ concentration (represented in this case only by the change in $\mathrm{C} 0$ ) increases the droplet concentration by more than a factor of two when $C 0$ is increased by a factor of three. This increase in concentration is similar to what was observed in the measured droplet concentrations. These results suggest that the observed differences in the LWC, droplet concentration and median volume diameter are the result of changes in the aerosol between the periods, rather that due to changes in the type of convection or other mesoscale forcing.

\section{Discussion}

\subsection{Overview}

As shown in Table 2, the overall aerosol composition measured was principally inorganic in nature. The sulphate mass concentrations are consistent with previous field studies in this location and in other non-polluted MBL sites (Coe et al., 2006; Allan et al., 2004a) with the amounts of POM representing a much smaller fraction. This apparent lack of a significant organic matter mass fraction is corroborated by the HTDMA and size-resolved CCN measurements which consistently showed the majority of the particles exhibiting the hygroscopicity that would be expected with principally inorganic aerosols.

The two main conditions observed during the study, dictated by the wind sector, were clean conditions when the air originated from the NE (period 2) and more polluted conditions when the wind was from the ESE (periods 1 and 3) and resulted in marked changes in both the aerosol composition and the in situ cloud properties. HYSPLIT back trajectory analysis performed using the NOAA Air Resources Laboratory web service ${ }^{5}$ (Fig. 11) indicates that there was a tendency for the air to come from the direction of populated islands to the east (principally the British Virgin Is-

\footnotetext{
${ }^{5}$ http://www.arl.noaa.gov/ready/hysplit4.html
}

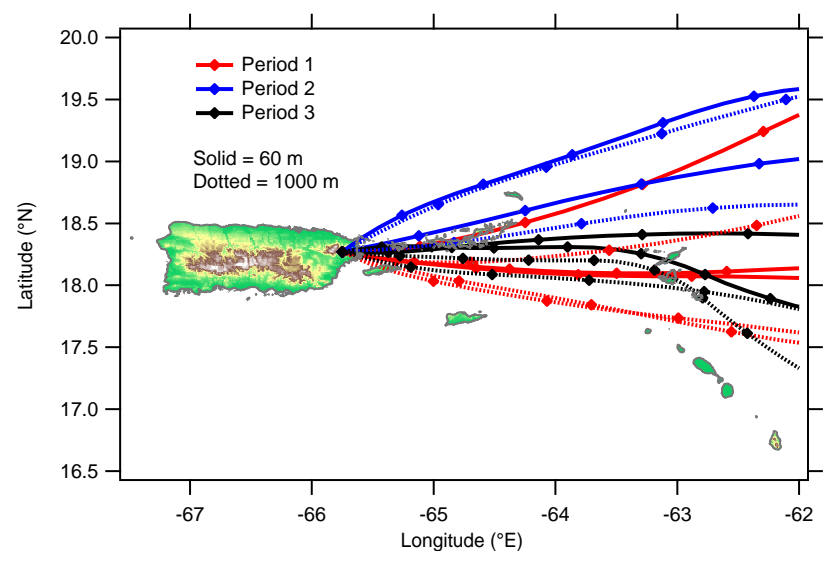

Fig. 11. Back trajectories for the three periods, arriving at the altitudes of the Cape San Juan and East Peak sites. Check marks are shown once every $3 \mathrm{~h}$. Note that the trajectories for period 2 are generally more northerly than those for the other periods. Vertical movement is not shown but all trajectories are within $100 \mathrm{~m}$ of their finishing altitudes within the region shown.

lands) during periods 1 and 3, with the airmasses having a more northerly origin during period 2 . The polluted periods were evident in increased numbers of particles (especially those below $100 \mathrm{~nm}$ in diameter), sulphate, EBC and nitrate, which was evident both in the measurements at sea level and within the cloud itself. The particles in the polluted conditions were also shown to, in part, be generally less hygroscopic, with a fraction exhibiting lower sub-saturated growth factors. This, along with the fact that the most significant amounts of organic matter and EBC were seen during this period, points to the additional Aitken-mode particles being produced by combustion sources upwind.

The addition of a primary aerosol is also manifested in an increase in CCN concentrations, but this increase is not proportional to the (much larger) increase in $\mathrm{CN}$, resulting in lower $\mathrm{CCN}$ to $\mathrm{CN}$ ratios for particles of a given size. The overall ratio of $\mathrm{CCN}$ to $\mathrm{CN}$ is likewise suppressed, although this may have more to do with the larger number of small particles under these conditions, as activation is very strongly dependent on size (Dusek et al., 2006). However, the greater number concentrations of larger $(>100 \mathrm{~nm})$ interstitial particles in the polluted cases would seem to suggest that size alone was not the governing factor controlling activation within the clouds observed. The measured changes in the cloud microphysics during the polluted cases would seem to suggest that even at the modest mass concentrations observed and in spite of the low hygroscopicity of the particles, the pollution from the upwind islands contributes to the $\mathrm{CCN}$ concentrations and has a measurable effect on the properties of warm clouds, namely an increase in cloud droplet number concentration, with a corresponding decrease in droplet diameter. 
Table 4. Results of cloud and rainwater analysis for periods 1 and 2: Ion mass derived from pH and Sigma after Krämer et al. (1996), insoluble mass with the Beckman Multisizer 3 Coulter Counter.

\begin{tabular}{lcccc}
\hline $\begin{array}{l}\text { Sample Source } \\
\text { (\# of samples) }\end{array}$ & $\begin{array}{c}\text { Ion Mass } \\
\mathrm{mg} \mathrm{l}^{-1}\end{array}$ & $\begin{array}{c}\text { Insolube Mass } \\
\mathrm{mg} \mathrm{l}^{-1}\end{array}$ & $\begin{array}{c}\text { Insoluble Number } \\
\mathrm{ml}^{-1}\end{array}$ & $\begin{array}{c}\text { Insoluble median diameter } \\
\mu \mathrm{m}\end{array}$ \\
\hline Period 1: Rainwater (3) & 5.1 & 0.06 & 12790 & 1.1 \\
Period 2: Rainwater (2) & 2.6 & 0.02 & 11234 & 0.9 \\
Period 1: Cloud water (3) & 40.9 & 0.4 & 23201 & 1.1 \\
Period 2: Cloud water (3) & 15.9 & 0.1 & 13133 & 1.1 \\
\hline
\end{tabular}

\subsection{Potential technical issues affecting organics}

Before arriving at specific conclusions regarding the reduced amounts of organic carbon compared to previous studies, it must first be considered that the disagreement between the measurements made in 1992 and 1995 and the current results are due to differences in the measurement techniques. The previous studies made use of the evolved gas analysis (EGA) of bulk samples collected over 8-12 h, whereas this work relies on the organic matter measurements by the AMS systems on times scales of several minutes. The systematic differences between the measurements are within the instrument uncertainties; Novakov et al. (1997, and references therein) estimate the uncertainty of the EGA technique to be around $10 \%$, whereas the error associated with a 36-h average of organic data during this study is about $\pm 7 \mathrm{ng} \mathrm{m}^{-3}$ (Allan et al., 2003). A discrepancy between the analytical techniques themselves is not deemed likely, as previous quantitative comparisons between AMS and similar offline organic measurements have been generally very good (Takegawa et al., 2005; Zhang et al., 2005; Topping et al., 2004; Gilardoni et al., 2007). The AMS is not able to detect refractory materials, which may cause a problem if the organic matter were to be bound in sea salt particles. However, this is not deemed to be the issue in this case, as thermograms from previous studies (Kirchstetter et al., 2000; Novakov et al., 1997) have shown the bulk of the organic matter to evolve at temperatures below $400^{\circ} \mathrm{C}$, which is well below the vaporizer temperature of the AMS $\left(550^{\circ} \mathrm{C}\right)$. The fact that the AMS does not measure larger particles is also not deemed to be the source of disagreement, as the 1995 study recorded organic mass concentrations within particles below $0.6 \mu \mathrm{m}$ in diameter, which is below the upper cutoff of the aerodynamic lens used in the AMS.

The AMS analysis relies on assumed values of the relative ionisation efficiencies and collection efficiency. The former values are based on laboratory characterisation work and with the exception of ammonium, have consistently been found to be robust between instruments and deployments (Allan et al., 2004a; Takegawa et al., 2005). It is possible that the actual collection efficiency could be greater than the 0.5 assumed, but this is only typically observed for pure ammo- nium nitrate or sulphuric acid particles or those with a very high water content (Crosier et al., 2007; Allan et al., 2004a). While considered unlikely, if this were the case, this would mean the actual organic mass concentrations would be lower than reported by up to a factor of 2 .

A potential source of discrepancy between the OC derived from EGA and the POM derived from both of the AMSs is a positive artefact caused by organic vapours that condense onto the filters during the long collection periods (Kirchstetter et al., 2000). The results for OC mass reported in 1992 for measurements made at El Yunque peak (Novakov and Penner, 1993) were more than a factor of two larger than those reported from the lighthouse in 1995 (Novakov et al., 1997). However, the samples taken in 1995 were also analyzed differently than those from 1992, correcting for the positive artefact using estimates of the excess material based on measurements with a backup filter, but as reported by Kirchstetter et al. (2000), in the absence of a denuder in front of the sampler to remove the organic vapours, the amount of condensed vapour may dominate the sample. This indicates that some of the organic matter previously found on filter samples may be volatile species condensing onto the substrate. While it is not expected that any such repartitioning should occur within the AMS itself, it is possible that it may occur in the sampling stack or inlet manifold used in this deployment. In the standard NOAA configuration used in this study, the stack subsample is heated to remove water from the sampled particles, so it is possible that some of the more volatile components of the organic fraction are being driven off. However, given the fact that a significant fraction reported in the previous studies only evolves at temperatures greater than $250^{\circ} \mathrm{C}$, repartitioning effects generating either positive or negative artefacts can only account for a discrepancy of a factor of around 2, which is not enough to explain the differences observed here.

\subsection{Comparisons with previous work}

If technical issues are not the main source of disagreement between the past and current studies, then it must be concluded that the organic fraction previously observed at this location is not totally ubiquitous. The study presented here took place in December whereas previous measurements 
Table 5. Comparison of sulphate, CN, CCN, Sulphate, POM, OC and droplet concentration measured by Novakov and co-workers in 1992 and 1995 (Novakov et al., 1994, 1997; Novakov and Penner, 1993) and in the 2004 campaign presented here. CSJ = Cape San Juan lighthouse, $\mathrm{EP}=$ East Peak, EY = El Yunque. POM was estimated from the OC using a factor of 1.5 during the 1992 study.

\begin{tabular}{|c|c|c|c|c|c|c|c|}
\hline Period: & $\begin{array}{l}1992 \text { EY } \\
\text { SE Winds }\end{array}$ & $\begin{array}{c}1995 \text { CSJ } \\
\text { ESE Winds }\end{array}$ & $\begin{array}{l}1995 \text { CSJ } \\
\text { NE Winds }\end{array}$ & $\begin{array}{c}2004 \text { CSJ } \\
\text { ESE Winds }\end{array}$ & $\begin{array}{c}2004 \text { EP } \\
\text { ESE Winds }\end{array}$ & $\begin{array}{c}2004 \text { CSJ } \\
\text { ENE Winds }\end{array}$ & $\begin{array}{c}2004 \mathrm{EP} \\
\text { ENE Winds }\end{array}$ \\
\hline Sulphate $\left(\mathrm{ng} \mathrm{m}^{-3}\right)$ & $1200(60)$ & $290(70)$ & $270(40)$ & $840(520)$ & $960(510)$ & $580(290)$ & \\
\hline $\mathrm{OC}\left(\mathrm{ng} \mathrm{m}^{-3}\right)$ & $660(140)$ & $410(110)$ & $340(70)$ & & & & \\
\hline $\operatorname{POM}\left(\mathrm{ng} \mathrm{m}^{-3}\right)$ & $1000(140)$ & & & $170(350)$ & $<700$ & $10(320)$ & \\
\hline $\mathrm{CN}\left(\mathrm{cm}^{-3}\right)$ & $2322(870)$ & & & 904 (498) & $1159(341)$ & $287(135)$ & $340(139)$ \\
\hline $\mathrm{CCN}\left(\mathrm{cm}^{-3}\right)$ & $558(170)$ & & & $373(164)$ & $236(66)$ & $171(122)$ & $157(95)$ \\
\hline $\mathrm{CCN} / \mathrm{CN}$ & $\begin{array}{c}0.26(0.08) \\
(0.5 \% \mathrm{SS})\end{array}$ & & & $\begin{array}{c}0.41 \\
(0.6 \% \mathrm{SS})\end{array}$ & $\begin{array}{c}0.20 \\
(0.6 \% \mathrm{SS})\end{array}$ & $\begin{array}{c}0.60 \\
(0.5 \% \mathrm{SS})\end{array}$ & $\begin{array}{c}0.46 \\
(0.5 \% \mathrm{SS})\end{array}$ \\
\hline$N_{\text {droplet }}\left(\mathrm{cm}^{-3}\right)$ & 304 (99) & & & & $519(186)$ & & $193(84)$ \\
\hline $\operatorname{LWC}\left(\mathrm{g} \mathrm{m}^{-3}\right)$ & $0.11(.04)$ & & & & $0.31(0.16)$ & & $0.24(0.10)$ \\
\hline Effective Radius $(\mu \mathrm{m})$ & $4.8(0.32)$ & & & & $6.1(0.5)$ & & $5.9(0.5)$ \\
\hline
\end{tabular}

were made in October, March, April and May, so it is possible that the production of tropical marine organic aerosols is a seasonal phenomenon, in the same way as was concluded by O'Dowd et al. (2004) for the northern Atlantic. Or given that some of the measurements took place 10 or more years apart, it could be indicative of a long-term trend of some description. It is also possible that these organic aerosols are produced in a spatially inhomogeneous manner. Previous studies had assumed that the prevailing source sector was northeasterly, bringing air in along the trade winds, but while the climatological wind direction is northeasterly, this work shows an analysis of the daily circulation pattern is essential to precisely locate the air mass origins. A potentially significant detail about the measurement area is the fact that there are many more inhabited islands to the east and southeast of Puerto Rico, which will be sources of organic aerosols in their own right. HYSPLIT back trajectory analysis, using archived wind field data, does indeed show that the wind was consistently originating from the SE during the 1992 measurements. However, these variations did not seem to affect the mass concentrations of organic carbon measured in 1995 (Novakov et al., 1997), when air came from both the northeast and southeast sectors. Also, the influence of anthropogenic emissions was ruled out by Mayol-Bracero et al. (2001), who did not detect any PAHs using GC-MS.

Whereas a major difference with previous studies was observed with respect to the general lack of organic aerosols, many of the other measurements are also dissimilar, as shown in Table 5, which lists average CN, CCN, sulphate, organics, droplet concentration, LWC and effective radius from this study and those of the 1992 and 1995 studies. The CN and $\mathrm{CCN}$ concentrations measured at the El Yunque site were significantly greater than at the East Peak, whereas the cloud droplet concentrations were smaller. This may be a manifestation of the differences in aerosol composition noted during the studies but differences in the instrumentation may also be a factor. The CN counter used in 1992 (a TSI Model 3022) has a lower size threshold than the TSI 3010 used here and the classical aerosol spectrometer probe (CASP) is an earlier, exclusively ground-based version of the FSSP. In addition, as stated earlier, the approach used to derive the number concentration from the FSSP during this study has an uncertainty of almost $40 \%$.

Novakov et al. (1994) observed that the cloud droplet concentration was insensitive to the sulphate concentration, which is apparently at odds with our CCN measurements, which are consistent with sulphate being the dominant component. However, as originally pointed out, the formation rate of sulphate is not necessarily the controlling factor in number concentrations and $\mathrm{CCN}$ measurements alone cannot conclusively show the significant controlling factor in the cloud droplet concentrations, as much will depend on the cloud dynamics. In this study, there is no evidence to suggest that the changes in cloud microphysical behaviour noted during this study are attributable to anything other than the influence of anthropogenic emissions and there is not enough variability within the clean case to observationally assess the influence of sulphate or any natural organics that may be present. More extensive measurements are needed to fully evaluate this. A quantitative closure exercise between aerosol properties and cloud microphysics would also go some way to addressing this and the other issues discussed but unfortunately, the data in this study is not deemed sufficient, owing to the unfortunate lack of a reliable sea salt measurement and the fact that there was no verifiable flow connectivity between the sites during these measurements. A quantitative closure between the aerosol composition, hygroscopicity and size-resolved CCN measurements may be possible, using models already available (e.g. Petters and Kreidenweis, 2007; Topping et al., 2005a, b) but will be highly complex and is considered outside the scope of this paper. 


\section{Conclusions}

The Puerto Rico Aerosol Cloud Interaction Study (PRACS) was an intensive, two-site field experiment that took place during December 2004 with the goal of studying in situ aerosol and cloud properties in a tropical marine environment and attempting to study the linkage between the two in a quasi Lagrangian manner. This built on previous studies that had taken place at this location. Aerosol properties measured at the sea level site included number, size, chemical composition, hygroscopicity and $\mathrm{CCN}$ behaviour, and used some of the more recent developments in instrumentation. At the mountain site, cloud base microphysics was studied in situ and droplet and rain water composition was measured using both the offline analysis of bulk samples and online instrumentation studying the droplet residuals downstream of a counterflow virtual impactor (CVI).

Generally speaking, the majority of the submicron, non sea salt aerosol encountered during the study was exclusively composed of sulphate, with the exception of a period of ESE winds where small amounts of organic matter and black carbon were detected and to a lesser extent, sulphate and nitrate were also enhanced. This extra component was manifested as additional particles mainly below $100 \mathrm{~nm}$ in diameter, consistent with urban or industrial primary emissions. These elevated the overall CCN concentrations, despite the added particles having lower hygroscopicities. The change in air mass origin, from clean to moderately polluted, was also detected in the cloud properties as an increase in droplet concentration and significant decrease in the median volume diameter. Changes also occurred in the interstitial and cloud droplet residual particles, with greater numbers of particles, notably so at larger sizes, not activating and the residual particles increasing in size overall. Increases in the sulphate, nitrate and insoluble material were also found in the cloud water consistent with anthropogenic emissions.

Unlike in previous studies, an organic fraction large enough to perturb the $\mathrm{CCN}$ properties of the aerosol was not observed in the clean sector and the controlling component was, if anything, non-sea salt sulphate. While this disagreement may be due to technical issues associated with differences in the methodologies, it is unlikely to be the sole reason. It could be that the organic matter in the region is not ubiquitous and is dependent on either seasonal biological activity or source region.

In order to answer the questions fully, a complete closure between aerosol and cloud measurements would be required, which would be difficult for this dataset and deemed outside of the scope of this paper. However, these observations do highlight many outstanding questions regarding the extent and effect of tropical aerosols on clouds, the organic fraction in particular. A long term sampling project in this environment and a detailed, systematic comparison with wind field analysis, possibly using more detailed tools such as that of Stohl et al. (2002), would go a long way to addressing the uncertainty of the true extent and origin of organic aerosols (both natural and anthropogenic) within this region. This would ideally be used in tandem with cloud microphysical measurements and models in order to assess what influence these aerosols have on tropical clouds.

Acknowledgements. The authors would like to thank the following: P. Sheridan and J. Ogren of the National Oceanographic and Atmospheric Administration (NOAA) Earth Systems Research Laboratory for their support with the aerosol measurements at Cape San Juan; J. Collett of Colorado State University for loan of the cloud water sampler; the Caribbean National Forest and the Federal Aviation Administration for access to the East Peak site and the Conservation Trust of Puerto Rico for access to the Cape San Juan lighthouse site. Coastline data used in the figures was provided by the National Geophysical Data Center, land relief data provided by the U.S. Geological Survey and back trajectories calculated using the NOAA Air Resources Laboratory HYSPLIT service. This project was funded by the Mexican Science Foundation (Conacyt grant \#45310), the Royal Society International Joint Projects scheme, the National Science Foundation (grant \#0342548) and the Max Planck Society. Special thanks to T. Novakov, whose critical review and helpful suggestions have greatly improved the manuscript.

\section{Edited by: D. Cziczo}

\section{References}

Allan, J. D., Jimenez, J. L., Williams, P. I., Alfarra, M. R., Bower, K. N., Jayne, J. T., Coe, H., and Worsnop, D. R.: Quantitative sampling using an aerodyne aerosol mass spectrometer -1 . Techniques of data interpretation and error analysis, J. Geophys. Res.Atmos., 108, 4090, doi:10.1029/2002JD002358, 2003.

Allan, J. D., Bower, K. N., Coe, H., Boudries, H., Jayne, J. T., Canagaratna, M. R., Millet, D. B., Goldstein, A. H., Quinn, P. K., Weber, R. J., and Worsnop, D. R.: Submicron aerosol composition at trinidad head, california, during itct $2 \mathrm{k} 2$ : Its relationship with gas phase volatile organic carbon and assessment of instrument performance, J. Geophys. Res.-Atmos., 109, D23S24 doi:10.1029/2003JD004208, 2004a.

Allan, J. D., Coe, H., Bower, K. N., Alfarra, M. R., Delia, A. E., Jimenez, J. L., Middlebrook, A. M., Drewnick, F., Onasch, T. B., Canagaratna, M. R., Jayne, J. T., and Worsnop, D. R.: A generalised method for the extraction of chemically resolved mass spectra from aerodyne aerosol mass spectrometer data, J. Aerosol. Sci., 35, 909-922, 2004b.

Baumgardner, D.: An analysis and comparison of 5 water droplet measuring-instruments, J. Clim. Appl. Meteorol., 22, 891-910, 1983.

Bond, T. C., Anderson, T. L., and Campbell, D.: Calibration and intercomparison of filter-based measurements of visible light absorption by aerosols, Aerosol Sci. Technol., 30, 582-600, 1999.

Bond, T. C. and Bergstrom, R. W.: Light absorption by carbonaceous particles: An investigative review, Aerosol Sci. Technol., 40, 27-67, 2006.

Bower, K. N., Choularton, T. W., Gallagher, M. W., Colvile, R. N., Beswick, K. M., Inglis, D. W. F., Bradbury, C., Martinsson, B. G., Swietlicki, E., Berg, O. H., Cederfelt, S. I., Frank, G., Zhou, 
J., Cape, J. N., Sutton, M. A., McFadyen, G. G., Milford, C., Birmili, W., Yuskiewicz, B. A., Wiedensohler, A., Stratmann, F., Wendisch, M., Berner, A., Ctyroky, P., Galambos, Z., Mesfin, S. H., Dusek, U., Dore, C. J., Lee, D. S., Pepler, S. A., Bizjak, M., and Divjak, B.: The great dun fell experiment 1995: An overview, Atmos. Res., 50, 151-184, 1999.

Canagaratna, M. R., Jayne, J. T., Jimenez, J. L., Allan, J. D., Alfarra, M. R., Zhang, Q., Onasch, T. B., Drewnick, F., Coe, H., Middlebrook, A., Delia, A., Williams, L. R., Trimborn, A. M., Northway, M. J., DeCarlo, P. F., Kolb, C. E., Davidovits, P., and Worsnop, D. R.: Chemical and microphysical characterization of ambient aerosols with the aerodyne aerosol mass spectrometer, Mass Spectrom. Rev., 26, 185-222, 2007.

Chandler, A. S., Choularton, T. W., Dollard, G. J., Gay, M. J., Gallagher, M. W., Hill, T. A., Jones, B. M. R., Penkett, S. A., Tyler, B. J., and Bandy, B.: A field-study of the oxidation of so2 in a cap cloud at great dun fell, Q. J. Roy. Meteor. Soc., 115, 397420, 1989.

Coe, H., Allan, J. D., Alfarra, M. R., Bower, K. N., Flynn, M. J., McFiggans, G. B., Topping, D. O., Williams, P. I., O'Dowd, C. D., Dall'Osto, M., Beddows, D. C. S., and Harrison, R. M.: Chemical and physical characteristics of aerosol particles at a remote coastal location, mace head, ireland, during namblex, Atmos. Chem. Phys., 6, 3289-3301, 2006,

http://www.atmos-chem-phys.net/6/3289/2006/.

Comarazamy, D. E., Gonzalez, J. E., Tepley, C. A., Raizada, S., and Pandya, R. V. R.: Effects of atmospheric particle concentration on cloud microphysics over arecibo, J. Geophys. Res.-Atmos., 111, D09205, doi:10.1029/2005JD006243, 2006.

Crosier, J., Allan, J. D., Coe, H., Bower, K. N., Formenti, P., and Williams, P. I.: Chemical composition of summertime aerosol in the po valley (italy), northern adriatic and black sea, Q. J. Roy. Meteor. Soc., 133, 61-75, doi:10.1002/qj.88, 2007.

Cubison, M. J., Coe, H., and Gysel, M.: A modified hygroscopic tandem dma and a data retrieval method based on optimal estimation, J. Aerosol. Sci., 36, 846-865, 2005.

DeCarlo, P. F., Slowik, J. G., Worsnop, D. R., Davidovits, P., and Jimenez, J. L.: Particle morphology and density characterization by combined mobility and aerodynamic diameter measurements. Part 1: Theory, Aerosol Sci. Technol., 38, 1185-1205, 2004.

Delene, D. J., Deshler, T., Wechsler, P., and Vali, G. A.: A balloon-borne cloud condensation nuclei counter, J. Geophys. Res.-Atmos., 103, 8927-8934, 1998.

Delene, D. J. and Deshler, T.: Calibration of a photometric cloud condensation nucleus counter designed for deployment on a balloon package, J. Atmos. Ocean Technol., 17, 459-467, 2000.

Demoz, B. B., Collett, J. L., and Daube, B. C.: On the caltech active strand cloudwater collectors, Atmos. Res., 41, 47-62, 1996.

Dusek, U., Frank, G. P., Hildebrandt, L., Curtius, J., Schneider, J., Walter, S., Chand, D., Drewnick, F., Hings, S., Jung, D., Borrmann, S., and Andreae, M. O.: Size matters more than chemistry for cloud-nucleating ability of aerosol particles, Science, 312, 1375-1378, 2006.

Forster, P., Ramaswamy, V., Artaxo, P., Berntsen, T., Betts, R., Fahey, D. W., Haywood, J., Lean, J., Lowe, D. C., Myhre, G., Nganga, J., Prinn, R., Raga, G., Schulz, M., and Dorland, R. V.: Changes in atmospheric constituents and in radiative forcing, in: Climate change 2007: The physical science basis, Contribution of working group $i$ to the fourth assessment report of the inter- governmental panel on climate change, edited by: Solomon, S., Qin, D., Manning, M., Chen, Z., Marquis, M., Averyt, K. B., Tignor, M., and Miller, H. L., Cambridge Univ. Press, Cambridge; New York, 129-234, 2007.

Frank, G., Dusek, U., and Andreae, M. O.: Technical note: Characterization of a static thermal-gradient ccn counter, Atmos. Chem. Phys., 7, 3071-3080, 2007,

http://www.atmos-chem-phys.net/7/3071/2007/.

Gilardoni, S., Russell, L. M., Sorooshian, A., Flagan, R. C., Seinfeld, J. H., Bates, T. S., Quinn, P. K., Allan, J. D., Williams, B., Goldstein, A. H., Onasch, T. B., and Worsnop, D. R.: Regional variation of organic functional groups in aerosol particles on four us east coast platforms during the international consortium for atmospheric research on transport and transformation 2004 campaign, J. Geophys. Res.-Atmos., 112, D10S27, doi:10.1029/2006JD007737, 2007.

Gysel, M., Crosier, J., Topping, D. O., Whitehead, J. D., Bower, K. N., Cubison, M. J., Williams, P. I., Flynn, M. J., McFiggans, G. B., and Coe, H.: Closure study between chemical composition and hygroscopic growth of aerosol particles during TORCH2, Atmos. Chem. Phys., 7, 6131-6144, 2007, http://www.atmos-chem-phys.net/7/6131/2007/.

Jayne, J. T., Leard, D. C., Zhang, X. F., Davidovits, P., Smith, K. A., Kolb, C. E., and Worsnop, D. R.: Development of an aerosol mass spectrometer for size and composition analysis of submicron particles, Aerosol Sci. Technol., 33, 49-70, 2000.

Kirchstetter, T. W., Novakov, T., Morales, R., and Rosario, O.: Differences in the volatility of organic aerosols in unpolluted tropical and polluted continental atmospheres, J. Geophys. Res.Atmos., 105, 26 547-26 554, 2000.

Krämer, M., Schüle, M., and Schütz, L.: A method to determine rainwater solutes from ph and conductivity measurements, Atmos. Environ., 30, 3291-3300, 1996.

Lance, S., Medina, J., Smith, J. N., and Nenes, A.: Mapping the operation of the dmt continuous flow ccn counter, Aerosol Sci. Technol., 40, 242-254, 2006.

Maria, S. F., Russell, L. M., Turpin, B. J., and Porcja, R. J.: Ftir measurements of functional groups and organic mass in aerosol samples over the caribbean, Atmos. Environ., 36, 5185-5196, 2002.

Mayol-Bracero, O. L., Rosario, O., Corrigan, C. E., Morales, R., Torres, I., and Perez, V.: Chemical characterization of submicron organic aerosols in the tropical trade winds of the caribbean using gas chromatography/mass spectrometry, Atmos. Environ., 35, 1735-1745, 2001.

McFiggans, G., Artaxo, P., Baltensperger, U., Coe, H., Facchini, M. C., Feingold, G., Fuzzi, S., Gysel, M., Laaksonen, A., Lohmann, U., Mentel, T. F., Murphy, D. M., O’Dowd, C. D., Snider, J. R., and Weingartner, E.: The effect of physical and chemical aerosol properties on warm cloud droplet activation, Atmos. Chem. Phys., 6, 2593-2649, 2006,

http://www.atmos-chem-phys.net/6/2593/2006/.

McMurry, P. H.: A review of atmospheric aerosol measurements, Atmos. Environ., 34, 1959-1999, 2000.

Mertes, S., Lehmann, K., Nowak, A., Massling, A., and Wiedensohler, A.: Link between aerosol hygroscopic growth and droplet activation observed for hill-capped clouds at connected flow conditions during febuko, Atmos. Environ., 39, 4247-4256, 2005.

Nenes, A., Chuang, P. Y., Flagan, R. C., and Seinfeld, J. H.: A theo- 
retical analysis of cloud condensation nucleus (ccn) instruments, J. Geophys. Res.-Atmos., 106, 3449-3474, 2001.

Novakov, T. and Penner, J. E.: Large contribution of organic aerosols to cloud-condensation-nuclei concentrations, Nature, 365, 823-826, 1993.

Novakov, T., Riveracarpio, C., Penner, J. E., and Rogers, C. F.: The effect of anthropogenic sulfate aerosols on marine cloud droplet concentrations, Tellus B, 46, 132-141, 1994.

Novakov, T., Corrigan, C. E., Penner, J. E., Chuang, C. C., Rosario, O., and Mayol-Bracero, O. L.: Organic aerosols in the caribbean trade winds: A natural source?, J. Geophys. Res.-Atmos., 102, 21 307-21313, 1997.

Novakov, T., Menon, S., Kirchstetter, T. W., Koch, D., and Hansen, J. E.: Aerosol organic carbon to black carbon ratios: Analysis of published data and implications for climate forcing, J. Geophys. Res.-Atmos., 110, D21205, doi:10.1029/2005JD005977, 2005.

O’Dowd, C. D., Facchini, M. C., Cavalli, F., Ceburnis, D., Mircea, M., Decesari, S., Fuzzi, S., Yoon, Y. J., and Putaud, J. P.: Biogenically driven organic contribution to marine aerosol, Nature, 431, 676-680, 2004.

Petters, M. D. and Kreidenweis, S. M.: A single parameter representation of hygroscopic growth and cloud condensation nucleus activity, Atmos. Chem. Phys., 7, 1961-1971, 2007, http://www.atmos-chem-phys.net/7/1961/2007/.

Quant, F. R., Caldow, R., Sem, G. J., and Addison, T. J.: Performance of condensation particle counters with three continuousflow designs, J. Aerosol. Sci., 23, S405-S408, 1992.

Quinn, P. K., Bates, T. S., Miller, T. L., Coffman, D. J., Johnson, J. E., Harris, J. M., Ogren, J. A., Forbes, G., Anderson, T. L., Covert, D. S., and Rood, M. J.: Surface submicron aerosol chemical composition: What fraction is not sulfate?, J. Geophys. Res.Atmos., 105, 6785-6806, 2000.

Roberts, G. C. and Nenes, A.: A continuous-flow streamwise thermal-gradient cen chamber for atmospheric measurements, Aerosol Sci. Technol., 39, 206-221, 2005.

Rose, D., Gunthe, S. S., Mikhailov, E., Frank, G. P., Dusek, U., Andreae, M. O., and Pöschl, U.: Calibration and measurement uncertainties of a continuous-flow cloud condensation nuclei counter (DMT-CCNC): CCN activation of ammonium sulfate and sodium chloride aerosol particles in theory and experiment, Atmos. Chem. Phys., 8, 1153-1179, 2008, http://www.atmos-chem-phys.net/8/1153/2008/.

Sheridan, P. J., Delene, D. J., and Ogren, J. A.: Four years of continuous surface aerosol measurements from the department of energy's atmospheric radiation measurement program southern great plains cloud and radiation testbed site, J. Geophys. Res.Atmos., 106, 20735-20 747, 2001.

Stohl, A., Eckhardt, S., Forster, C., James, P., Spichtinger, N., and Seibert, P.: A replacement for simple back trajectory calculations in the interpretation of atmospheric trace substance measurements, Atmos. Environ., 36, 4635-4648, 2002.
Takegawa, N., Miyazaki, Y., Kondo, Y., Komazaki, Y., Miyakawa, T., Jimenez, J. L., Jayne, J. T., Worsnop, D. R., Allan, J. D., and Weber, R. J.: Characterization of an aerodyne aerosol mass spectrometer (ams): Intercomparison with other aerosol instruments, Aerosol Sci. Technol., 39, 760-770, 2005.

Topping, D. O., Coe, H., McFiggans, G. B., Burgess, R., Allan, J. D., Alfarra, M. R., Bower, K. N., Choularton, T. W., Decesari, S., and Facchini, M. C.: Aerosol chemical characteristics from sampling conducted on the island of jeju, korea during ace asia, Atmos. Environ., 38, 2111-2123, 2004.

Topping, D. O., McFiggans, G. B., and Coe, H.: A curved multicomponent aerosol hygroscopicity model framework: Part 1 - inorganic compounds, Atmos. Chem. Phys., 5, 1205-1222, 2005a.

Topping, D. O., McFiggans, G. B., and Coe, H.: A curved multicomponent aerosol hygroscopicity model framework: Part 2 including organic compounds, Atmos. Chem. Phys., 5, 1223 1242, 2005b.

Turpin, B. J. and Lim, H. J.: Species contributions to pm2.5 mass concentrations: Revisiting common assumptions for estimating organic mass, Aerosol Sci. Technol., 35, 602-610, 2001.

Twomey, S. and Wojciechowski, T. A.: Observations of the geographical variation of cloud nuclei, J. Atmos. Sci., 26, 648-651, 1969.

Twomey, S.: The influence of pollution of the shortwave albedo of clouds, J. Atmos. Sci., 34, 1149-1152, 1977.

Weingartner, E., Saathoff, H., Schnaiter, M., Streit, N., Bitnar, B., and Baltensperger, U.: Absorption of light by soot particles: Determination of the absorption coefficient by means of aethalometers, J. Aerosol. Sci., 34, 1445-1463, 2003.

Wendisch, M.: A quantitative comparison of ground-based fssp and pvm measurements, J. Atmos. Ocean Technol., 15, 887-900, 1998.

Zhang, Q., Worsnop, D. R., Canagaratna, M. R., and Jimenez, J. L.: Hydrocarbon-like and oxygenated organic aerosols in pittsburgh: Insights into sources and processes of organic aerosols, Atmos. Chem. Phys., 5, 3289-3311, 2005, http://www.atmos-chem-phys.net/5/3289/2005/.

Zhang, Q., Jimenez, J. L., Canagaratna, M. R., Allan, J. D., Coe, H., Ulbrich, I., Alfarra, M. R., Takami, A., Middlebrook, A. M., Sun, Y. L., Dzepina, K., Dunlea, E., Docherty, K., DeCarlo, P. F., Salcedo, D., Onasch, T., Jayne, J. T., Miyoshi, T., Shimono, A., Hatakeyama, S., Takegawa, N., Kondo, Y., Schneider, J., Drewnick, F., Borrmann, S., Weimer, S., Demerjian, K., Williams, P., Bower, K., Bahreini, R., Cottrell, L., Griffin, R. J., Rautiainen, J., Sun, J. Y., Zhang, Y. M., and Worsnop, D. R.: Ubiquity and dominance of oxygenated species in organic aerosols in anthropogenically-influenced northern hemisphere midlatitudes, Geophys. Res. Lett., 34, L13801, doi:10.1029/2007GL029979, 2007. 